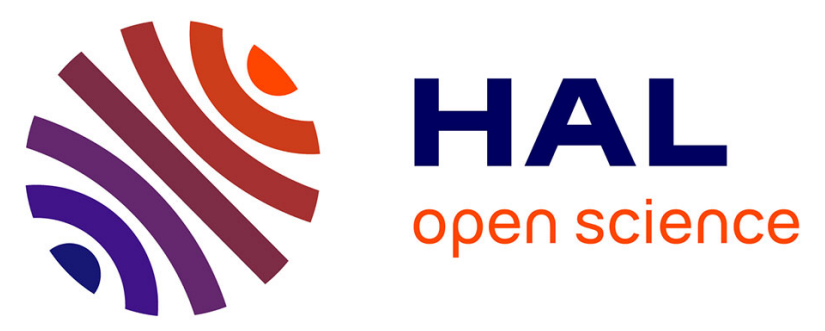

\title{
Development of Atlantic cod () exposed to produced water during early life stages: Effects on embryos, larvae, and juvenile fish
}

Sonnich Meier, H. Craig Morton, Gunnar Nyhammer, Bjørn Einar Grøsvik, Valeri Makhotin, Audrey Geffen, Stepan Boitsov, Karen Anita Kvestad, Anneli Bohne-Kjersem, Anders Goksøyr, et al.

\section{To cite this version:}

Sonnich Meier, H. Craig Morton, Gunnar Nyhammer, Bjørn Einar Grøsvik, Valeri Makhotin, et al.. Development of Atlantic cod () exposed to produced water during early life stages: Effects on embryos, larvae, and juvenile fish. Marine Environmental Research, 2010, 70 (5), pp.383. 10.1016/j.marenvres.2010.08.002 . hal-00631697

\section{HAL Id: hal-00631697 https://hal.science/hal-00631697}

Submitted on 13 Oct 2011

HAL is a multi-disciplinary open access archive for the deposit and dissemination of scientific research documents, whether they are published or not. The documents may come from teaching and research institutions in France or abroad, or from public or private research centers.
L'archive ouverte pluridisciplinaire HAL, est destinée au dépôt et à la diffusion de documents scientifiques de niveau recherche, publiés ou non, émanant des établissements d'enseignement et de recherche français ou étrangers, des laboratoires publics ou privés. 


\section{Accepted Manuscript}

Title: Development of Atlantic cod (Gadus morhua) exposed to produced water during early life stages: Effects on embryos, larvae, and juvenile fish

Authors: Sonnich Meier, H. Craig Morton, Gunnar Nyhammer, Bjørn Einar Grøsvik, Valeri Makhotin, Audrey Geffen, Stepan Boitsov, Karen Anita Kvestad, Anneli Bohne-

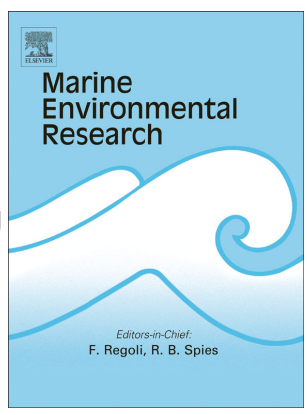
Kjersem, Anders Goksøyr, Arild Folkvord, Jarle Klungsøyr, Asbjørn Svardal

PII: S0141-1136(10)00117-0

DOI: 10.1016/j.marenvres.2010.08.002

Reference: MERE 3468

To appear in: Marine Environmental Research

Received Date: 8 December 2009

Revised Date: 10 August 2010

Accepted Date: 13 August 2010

Please cite this article as: Meier, S., Morton, H.C., Nyhammer, G., Grøsvik, B.E., Makhotin, V., Geffen, A., Boitsov, S., Kvestad, K.A., Bohne-Kjersem, A., Goksøyr, A., Folkvord, A., Klungsøyr, J., Svardal, A. Development of Atlantic cod (Gadus morhua) exposed to produced water during early life stages: Effects on embryos, larvae, and juvenile fish, Marine Environmental Research (2010), doi: 10.1016/ j.marenvres.2010.08.002

This is a PDF file of an unedited manuscript that has been accepted for publication. As a service to our customers we are providing this early version of the manuscript. The manuscript will undergo copyediting, typesetting, and review of the resulting proof before it is published in its final form. Please note that during the production process errors may be discovered which could affect the content, and all legal disclaimers that apply to the journal pertain. 
1 Development of Atlantic cod (Gadus morhua) exposed to produced water

2 during early life stages: Effects on embryos, larvae, and juvenile fish.

3

4 Sonnich Meier ${ }^{a^{*}}$, H. Craig Morton ${ }^{a}$, Gunnar Nyhammer ${ }^{b}$, Bjørn Einar Grøsvik ${ }^{\mathrm{ab}}$, Valeri

5 Makhotin $^{c}$, Audrey Geffen $^{\mathrm{b}}$, Stepan Boitsov ${ }^{\mathrm{a}}$, Karen Anita Kvestad ${ }^{\mathrm{b}}$, Anneli Bohne-Kjersem ${ }^{\mathrm{b}}$,

$6 \quad$ Anders Goks $\varnothing \mathrm{yr}^{\mathrm{b}}$, Arild Folkvord ${ }^{\mathrm{b}}$, Jarle Klungs $\varnothing \mathrm{yr}^{\mathrm{a}}$, Asbjørn Svardal ${ }^{\text {ad }}$

7

$8 \quad$ Institute of Marine Research, Bergen, Norway

$9{ }^{b}$ Department of Molecular Biology/Biology, University of Bergen, Norway

10 'Department of Ichthyology, Moscow State University, Russia.

11 dDepartment of Medicine, Section for Pharmacology, University of Bergen, Norway

$14 *$ Corresponding author:

15 Sonnich Meier

16 Institute of Marine Research

17 P.O.Box 1870, N-5817 Nordnes, Bergen, Norway

18 Fax: +4755238555

19 E-mail: Sonnich.meier@imr.no 


\section{Abstract}

Produced water (PW) contains numerous toxic compounds of natural origin, such as dispersed oil, metals, alkylphenols (APs), and polycyclic aromatic hydrocarbons (PAHs). In addition, PW also contains many different chemicals which have been added during the oil production process. In the study described here, cod were exposed to real PW collected from an oil production platform in the North Sea. This was done in order to best recreate the most realistic field-exposure regime in which fish will be affected by a wide range of chemicals. The biological effects found in this study therefore cannot be assigned to one group of chemicals alone, but are the result of exposure to the complex chemical mixture found in real PW. Since APs are well known to cause endocrine disruption in marine organisms, we focused our chemical analysis on APs in an attempt to better understand the long term effects of APs from PW on the biology of fish. In this study, cod were exposed to several concentrations of real PW and $17 \beta$-oestradiol $\left(E_{2}\right)$, a natural oestrogen, at different developmental stages. Cod were exposed to PW either during the embryo and early larvae stage (up to 3 months of age) or during the early juvenile stage (from $3-6$ months of age). Results showed that, in general, APs bioconcentrate in fish tissue in a dose and developmental stage dependent manner during PW exposure. However, juveniles appeared able to effectively metabolise the short chain APs. Importantly, PW exposure had no effect on embryo survival or hatching success. However, 1\% PW clearly interfered with the development of normal larval pigmentation. After hatching most of the larvae exposed to 1\% PW failed to begin feeding and died of starvation. This inability to feed may be linked to the increased incidence of jaw deformities seen in these larvae. In addition, cod exposed to 1\% PW, had significantly higher levels of the biomarkers vitellogenin and CYP1A in plasma 
43 44 PW.

45

46

47 Key words: Alkylphenols, Early lifestages, Embryo, Endocrine disruption, Cod, Gadus morhua, 48 and liver, respectively. No similar effects were seen in cod exposed to either $0.1 \%$ or $0.01 \%$

Larvae, Produced water, Pigmentation, Sex differentiation. 


\section{Introduction}

Produced water (PW) is a combination of formation water, condensation water, injection water and water used for desalting oil. Therefore, PW is a complex mixture of seawater, dispersed oil, PAHs and other dissolved hydrocarbons, organic acids, alkylphenols (APs), metals, and traces of production chemicals (Neff, 2002). As oilfields age, the amount of water injected into the reservoir to help maintain reservoir pressure increases. Since many oil fields in the North Sea are approaching the end of their productive lives the amount of water injected into the reservoirs has increased rapidly, resulting in a huge increase in the amount of PW discharged into the sea (Durell et al., 2006). From 1990 to 2006 the annual discharge of PW from the Norwegian sector increased from 10 mill $\mathrm{m}^{3}$ to $162 \mathrm{mill} \mathrm{m}^{3}$, and together with PW from the British, Danish and Dutch sectors, the total amount of PW released into the North Sea is estimated to be more than 500 mill $\mathrm{m}^{3}$ per year.

APs are natural components of crude oil (loppolo-Armanios et al., 1992), and as a result of their solubility in water high concentrations are still present in the aqueous phase after oil/water separation (Boitsov et al., 2007). Oil production platforms, therefore, release large amounts of APs into the seas via PW. APs have been shown to mimic the effects of the natural female sex hormone oestrogen, resulting in disruption of the endocrine and reproductive systems (Meier et al., 2007; Tollefsen and Nilsen, 2008). Previously, the main focus of research has been on the effects of long-chain APs (octyl-, and nonylphenols) which are degradation products of non-ionic surfactants known as AP-ethoxylates. More recently, it has been shown that APs with shorter chain lengths can also bind to the oestrogen receptor and produce mild oestrogenic effects (Tollefsen and Nilsen, 2008). 
There is a huge amount of literature available describing the effects of APs on the endocrine system of vertebrates, and on gonadal development in fish in particular (Arukwe and Goksøyr, 1998; Servos, 1999). APs affect a number of reproductive parameters in fish, including induction of plasma vitellogenin ( $\mathrm{Vtg})$ in male and juvenile fish (Jobling and Sumpter, 1993; White et al., 1994), inhibition of spermatogenesis (Jobling and Sumpter, 1993; Gimeno et al., 1998; Miles-Richardson et al., 1999; Weber et al., 2002), and oogenesis (Tanaka and Grizzle, 2002; Weber et al., 2003). In addition to binding to the oestrogen receptor, APs have also been shown to affect the brain-pituitary-gonad axis via induction/inhibition of the gonadotropins (Harris et al., 2001; Yadetie and Male, 2002) and to have direct effects on steroidogenesis (Yokota et al., 2005; Arukwe, 2005).

In many fish species sexual differentiation appears to be a relatively plastic process that has proved to be especially vulnerable to the endocrine-disrupting effects of APs (Gimeno et al., 1996; Seki et al., 2003; Gronen et al., 1999; Kang et al., 2003; Knorr and Braunbeck, 2002). Very little is known about the developmental processes that govern sexual differentiation in fish and especially in marine fish like Atlantic cod (Gadus morhua). Like several other fish species, cod likely exhibit specific "developmental windows" during larval development in which they are especially vulnerable to the effects of endocrine-disrupting chemicals and other environmental toxins (Gimeno et al., 1996; Devlin and Nagahama, 2002; van Aerle et al., 2002). In salmonids like rainbow trout (Oncorhynchus mykiss), a sensitive developmental window affecting sexual differentiation is known to occur early in the larval stage (Billard, 1992). However, in several marine fish the developmental window important for sexual 
differentiation occurs later, at the juvenile stage after metamorphosis (Blazquez et al., 1998; Hendry et al., 2002; Chiasson et al., 2008)

Recently, Chiasson et al. (2008) have studied gonadal differentiation in Atlantic cod and haddock (Melanogrammus aeglefinus). They found that female cod appear before males, with ovarian cavities first observed at 102 days post hatch (dph) when the fish were $27 \mathrm{~mm}$ long (total length, TL). This is similar to what is seen in other marine species like Atlantic halibut (Hippoglossus hippoglossus) (Hendry et al., 2002). Male cod were first positively identified (by the appearance of testis containing primary spermatogonia) at $221 \mathrm{dph}(\mathrm{TL}=$ $94 \mathrm{~mm})$.

Although a large amount of literature exists concerning the short-term toxic effects of exposure to high concentrations of APs and PW, only a few studies have examined more long-term effects. This study was specifically designed to examine the long-term effects on cod exposed to real PW during specific stages in their early development. Our chemical analysis focused mainly on the AP fraction of PW due to their known oestrogenic properties. The aim of this study was to investigate whether cod exposed to realistic concentrations of PW during early life suffer from decreased fitness. As measures of fitness, survival, growth, and frequency of malformations were studied. In addition, expression of the protein biomarkers vitellogenin (Vtg) and cytochrome P450 (CYP1A) were analysed by ELISA.

The fish described in this study were monitored until sexual maturation and the long term effects of PW on gonad development and reproductive success analysed. The results of that study will be published elsewhere. 


\section{Materials and methods}

\subsection{Rationale for exposure regimens}

The aim of this study was to investigate the effects of realistic doses of PW on the sexual differentiation and fitness of cod exposed to PW during early life. PW, released from an oilproduction platform into the sea is quickly diluted. Previous computer-modelling studies have concluded that PW is diluted approximately $1: 30$ at $10 \mathrm{~m}, 1: 100$ at $100 \mathrm{~m}$, and 1:1000 at $1 \mathrm{~km}$ from the outlet pipe (Neff, 2002). Additional results from modelling and field measurements have shown that the concentration of dispersed oil present in the North Sea in an area of $50-100 \mathrm{~km}$ surrounding the largest oilfields is approximately 1-3 ppb, which roughly corresponds to a dilution factor of 1:10,000 (Rye et al., 1998). In the study described herein, fish were exposed to three different concentrations of PW that reflects the estimated concentrations found in the North Sea (Table 1). Cod were exposed to PW diluted 1:100 (1\% v/v, high dose group, H-PW), 1:1000 (0.1\% v/v, medium dose group, M-PW), and 1:10,000 (0.01\% v/v, low dose group, L-PW). In addition to the three PW exposed groups, another group of fish were exposed to $10 \mu \mathrm{g} \mathrm{I} \mathrm{I}^{-1} 17 \beta$-oestradiol $\left(E_{2}\right)$ to study the effects of high concentrations of oestrogenic compounds. A further group of fish were maintained in clean seawater throughout the experiment (unexposed fish, U).

\subsection{Cod eggs}

The eggs used in this study were obtained from wild cod caught in Tysfjorden in Lofoten, Norway. For spawning, one male and one female fish were place in a spawning tank and the resultant eggs collected from a filter placed under the runoff outlet. To ensure a realistic 
141

142

143

144

level of biological variation in this study, eggs collected from five separate pairs of spawning cod were mixed. The average egg diameter (D) from each spawning pair was measured, and the number of eggs calculated according to the following formula: $\mathrm{N}$ (number of eggs per $m L)=1222 x D^{-2.71}$, (Kjesbu, 1989). Using this formula, 60,000 eggs $(12,000$ from each of the five pairs) were added to $100 \mathrm{~L}$ of water in each exposure tank.

\subsection{Description of the PW exposure experiments}

The experiments were conducted from March to December 2004. Fertilized eggs were collected over 2 days in March 2004 (25-26/03). Fifty percent hatching occurred on 13/04. Three separate exposure experiments were performed as described below (see also Figure 1).

\subsubsection{Experiment 1: PW exposure of cod eggs and yolk-sac larvae in multi-well trays}

Fertilized cod eggs (1-2 days old) from each of the 5 spawning pairs were transferred to the IMR laboratory in Bergen and incubated in 24-well plates (NUNC) (one egg per well). Five parallel exposure experiments were conducted: one for each individual family (spawning pair). For each family 16 plates containing 384 eggs in total were set up. The plates were divided into four groups and exposed to H-PW, M-PW, L-PW and normal seawater. Therefore, each treatment group consisted of 480 eggs divided into 20 plates (four plates from each of the 5 families per treatment group). The plates were incubated at $5^{\circ} \mathrm{C}$, and the water was changed every second day. The eggs, and subsequent larvae, were examined microscopically every second day. Survival rate, hatching success, and frequency of lethal deformities were recorded until 3 days post-hatch (dph). 


\subsubsection{Experiment 2A: Exposure of cod eggs and early larvae to PW}

166

167

168

169

170

171

172

Three parallel $100 \mathrm{~L}$ tanks, each containing 60,000 fertilized cod eggs $(12,000$ eggs from each family; 1-2 days post fertilization), were subjected to one of the five different exposure regimens described in section 2.1 for 23 days (in March/April 2004), until 3 dph. The larvae were counted and 6500 from each tank were transferred to a fresh $100 \mathrm{~L}$ tank and the exposure continued for 67 days (473 degree-days), through the whole start-feeding phase.

At the end of this 90 day period (in June 2004) the fish were approximately $2 \mathrm{~cm}$ in length and $10 \mathrm{mg}$ in weight (dry weight). The surviving fish from each exposure regimen were pooled and 200 randomly selected early juveniles transferred into $500 \mathrm{~L}$ tanks containing normal seawater. All fish in the H-PW group died during this 90 day exposure regimen so no longer-term studies could be performed on this group. The fish (from the remaining four treatment groups) were maintained in these $500 \mathrm{~L}$ tanks for approximately 7 months (until December 2004).

\subsubsection{Experiment 2B: Exposure of cod to PW from 3-6 months of age}

For this experiment 100,000 cod eggs $(20,000$ eggs from each of the 5 spawning pairs) were used. The eggs and larvae were maintained in an identical manner to those in Experiment $2 \mathrm{~A}$ except that they were incubated in clean seawater for 3 months until the early juvenile stage (average length $3.1 \pm 0.5 \mathrm{~cm}$ ). After 3 months, 250 fish were randomly transferred into each of ten $500 \mathrm{~L}$ tanks. Separate groups of fish were then exposed to one of the five treatments as described in section 2.1 ( 2 parallel tanks per treatment). The exposure lasted for 78 days from the early juvenile to juvenile phase (from July to September 2004), at which time the 
187

188

189

190

191

192

193

194

195

196

197

198

199

200

201

202

203

204

205

206

207

208

fish were approximately $11 \mathrm{~cm}$ in length and around $13 \mathrm{~g}$ in weight. The fish were maintained in these tanks for approximately 3 months (until December 2004).

\subsection{Tank setup and dilution of $P W$ in experiments $2 A$ and $2 B$}

The fish in experiments $2 \mathrm{~A}$ and $2 \mathrm{~B}$ were maintained in $100 \mathrm{~L}$ and $500 \mathrm{~L}$ tanks during the PW exposure as described. Clean seawater was added to all treatment tanks from a shared header-tank by gravity flow. Water from all PW header-tanks was diluted 1:100 before being added to the exposure tanks by adjusting the flow rates of the feeder pumps. In experiment $2 \mathrm{~A}$ the flow rate during the embryo phase was $25 \mathrm{ml} / \mathrm{min}$ from the seawater header tank and $0.25 \mathrm{ml} / \mathrm{min}$ from the $\mathrm{PW}$ or $17 \beta$-oestradiol $\left(\mathrm{E}_{2}\right)$ header tanks. During the larval phase the initial flow rate started at $50 \mathrm{ml} / \mathrm{min}$ clean seawater and $0.5 \mathrm{ml} / \mathrm{min}$ diluted $\mathrm{PW}$ or $\mathrm{E}_{2}$, and was gradually raised to $500 \mathrm{ml} / \mathrm{min}$ seawater and $5 \mathrm{ml} / \mathrm{min}$ diluted $\mathrm{PW}$ or $\mathrm{E}_{2}$ as the fish increased in size. One PW header tank was set up for each exposure group (three PW header tanks for experiment $2 \mathrm{~A}$ and three for experiment $2 \mathrm{~B}$ ). The header tank feeding the $\mathrm{H}-\mathrm{PW}$ exposure tanks contained undiluted PW; the header tank feeding the M-PW exposure tanks contained $100 \mathrm{ml} \mathrm{PW}$ per L seawater; and the header tank feeding the L-PW exposure tanks contained $10 \mathrm{ml} P W$ per $L$ seawater. Header tanks containing $1 \mathrm{mg} \mathrm{l}^{-1} E_{2}$ were also set up to feed the $E_{2}$ exposure tank (E). Ten $\mathrm{mg} \mathrm{E}_{2}$ was first dissolved in one $\mathrm{ml}$ ethanol and $100 \mu \mathrm{L}$ of this stock solution was added per $L$ of seawater. The nominal concentration of $E_{2}$ was therefore $10 \mu \mathrm{g} \mathrm{I}^{-}$

${ }^{1}$. The flow rate from all header tanks was monitored daily.

\subsection{Collection and treatment of PW}


The exposure regimen in this study was carried out with PW obtained from the Oseberg C oil production platform located in the North Sea off the west coast of Norway. The PW was collected in four $1000 \mathrm{~L}$ tanks and transferred to land by boat. The PW was then aliquoted into $25 \mathrm{~L}$ containers and frozen at $-30^{\circ} \mathrm{C}$ until needed. Frozen PW was allowed to thaw over a period of 24 hours, bubbled with air for 5 minutes using an aquarium pump to remove accumulated hydrogen sulphide $\left(\mathrm{H}_{2} \mathrm{~S}\right)$, before dilution and addition to the exposure tanks.

\subsection{Feeding}

Newly hatched larvae were fed with natural zooplankton, collected by filtering seawater through a Hydrotech drum filter. The collected zooplankton consisted predominantly of copepods at various developmental stages. The zooplankton concentration was measured daily and kept at approximately 1000 zooplankton per L. For the first four weeks the larvae were fed with zooplankton retained between 80 and $250 \mu \mathrm{m}$ mesh size. As the fish increased in size they were eventually fed with zooplankton retained between $350 \mu \mathrm{m}$ and $1000 \mu \mathrm{m}$. Two types of cultivated plankton algae (Isochrysis galbana and Rhodomonas sp.) were also added to the tanks daily. Fish were subsequently weaned onto marine fish feed pellets (Dana Feed, Horsens, Denmark), and fed eight times every day from automatic feeders placed over the tanks. The fish were fed with successively larger pellets as they grew.

In experiment $2 \mathrm{~A}, 40$ eggs from each treatment group were incubated in a $1 \mathrm{~L}$ beaker. After hatching these larvae were not fed, but were monitored daily until all the larvae died of hunger (unfed group). 


\subsection{Temperature and light regimen}

235

236

237

Experiment 1 was performed at a constant $5^{\circ} \mathrm{C}$ in a climate room. In experiments $2 \mathrm{~A}$ and $2 \mathrm{~B}$, the average temperature in the tanks during the embryo phase was $4.9^{\circ} \mathrm{C}$. The temperature was then gradually increased to $8.6^{\circ} \mathrm{C}$ throughout the larval phase and to $12^{\circ} \mathrm{C}$ during the early juvenile stage. The fish in the tanks were maintained under day length conditions for Bergen, Norway.

\subsection{Chemical analysis of water and fish}

The concentration of APs present in the diluted PW header tanks and in the exposure tanks was monitored regularly. Using these data the empirical dilution factor of APs in the exposure tanks relative to undiluted PW was calculated. The uptake of APs into fish tissue was measured at three different time points: yolk sack larvae from experiment $2 \mathrm{~A}$ were analysed at $3 \mathrm{dph}$ (after 22 days of exposure to PW, $\mathrm{E}_{2}$, or clean seawater); early juveniles from experiment 2A were analysed at $71 \mathrm{dph}$ (after 90 days of exposure); and late juveniles from experiment $2 \mathrm{~B}$ were analysed directly following the 78 day exposure period detailed above. The concentrations of 52 APs were measured in the water and in the fish tissue according to previously published methods (Boitsov et al., 2004; Meier et al., 2005). Concentrations of PAHs present in the PW and in the exposure tanks was also measured according to previously published methods (Boitsov et al., 2004), except that PAH standards labelled with stable isotopes were used in addition to the internal AP standard. 
255

256

257

258

259

260

261

262

263

264

265

266

267

268

269

270

271

272

273

274

275

276

277

\subsection{Sampling}

Fish were sampled multiple times during the course of experiments $2 \mathrm{~A}$ and $2 \mathrm{~B}$ as follows. In experiment 2A, larvae were sampled 7 times between March and June ( $3 \mathrm{dph}$ to $67 \mathrm{dph}$ ) (see Figure 1). At each sampling, 15 larvae from each tank were randomly selected, euthanized, and their length and dry weight measured. Whether the larvae had begun feeding was assessed by microscopic examination of the stomach. The fish in experiment $2 \mathrm{~A}$ were sampled 5 times (roughly once a month) between June and December (between 3 and 9 months post hatch). In experiment $2 \mathrm{~B}$ fish were sampled 6 times between June and December. During these samplings, 50 fish were randomly selected, removed from the tank, individually weighed and returned to the tank. During the last sampling (in December) all the fish in each tank (approx. 200-250) were removed and individually weighed and measured. Finally, 125 fish from each exposure group were transferred to sea cages at the Austevoll research station as part of a longer term study (manuscript in preparation). The remaining fish in each group were slaughtered, and their sex was determined by morphological examination.

\subsection{Sampling for biomarker analysis}

At the end of the exposure period in experiment $2 \mathrm{~A}$, whole larvae were sampled for proteomic studies and the results are presented elsewhere (Bohne-Kjersem et al., 2010). At the end of the exposure period in experiment $2 \mathrm{~B}$, liver samples were taken for proteomic analysis (Bohne-Kjersem et al., in preparation). Blood and liver samples from experiments 2B were also analysed for the presence of the biomarkers Vtg and CYP1A, respectively (Nilsen et al., 1998). 


\subsection{ELISA of CYP1A and Vtg}

A quantitative ELISA kit (Biosense, Bergen, Norway) was used to measure the Vtg levels in plasma of juvenile cod (Scott et al., 2006a). A semi-quantitative ELISA using a monoclonal anti-cod CYP1A antibody (clone NP7; Biosense, Bergen, Norway) diluted 1:1000 was used to measure CYP1A levels in the livers of juvenile cod (Nilsen et al., 1998).

\subsection{Statistical analyses}

The normality of each data sample and homogeneity of group variances were examined and when necessary the data were log transformed prior to testing. Differences between groups were analyzed by one-way ANOVA followed by a Dunnett's post test for normally distributed data or Kruskal-Wallis non-parametric test followed by Dunn's post test when data failed tests of normality. The statistical analyses were all performed using XLSTAT software (Addinsoft, US). 


\section{Results}

\subsection{Chemical analysis of the PW}

294

295

296

297

298

Continual analysis of the PW obtained from Osberg $\mathrm{C}$ throughout the exposure phase demonstrated that the AP profile and concentration remained constant over time (Figure 2). Our data also showed that freezing and thawing the PW had no effect on the AP profile or concentration (Figure 2). The average concentration of all APs of each chain length (from phenol to C9) was also measured (Table 2). The AP profile and relative concentrations in the PW obtained from Oseberg C for this study are similar to those measured previously in PW from the same platform (Boitsov et al., 2004; Boitsov et al., 2007). The AP data also showed how the AP concentration in PW falls as the solubility in water decreased (Table 2). The PW contained high concentrations of the most water soluble APs, phenol and cresol (CO, C1), but the relatively insoluble long-chain APs $(\geq C 6)$ were present at much lower concentrations (down to the $\mathrm{ng}^{-1}$ range) (Table 2 ).

\subsection{Chemical analysis of the water in the PW exposure tanks}

A clear concentration gradient of APs between the different treatment groups $(\mathrm{H}-\mathrm{PW}>\mathrm{M}-$ $P W>L-P W \approx U$ ) was observed. In addition, the dilution factor of the most volatile components, phenol and cresol, was markedly lower than the nominal concentration. This can most likely be explained by the fact that these compounds are extremely volatile and evaporate faster than they can be replenished despite the continual flow of PW into the exposure tanks. For the long-chain APs (C2-C5), the actual measured concentration was similar to the nominal concentration, at least in the H-PW and M-PW tanks. The dilution factor of the L-PW was so 
great that the AP concentrations measured were similar to the background levels present in the normal seawater added to the tanks containing unexposed fish (U).

\subsection{PAH measurements}

Typically, for PW originating from Oseberg C, approximately $30 \%$ of the PAHs present consisted of naphthalene and methyl-naphthalene (Durell et al., 2006). The relative absence of the highly volatile light PAHs was most likely due to the "airing" of the PW to remove $\mathrm{H}_{2} \mathrm{~S}$ gas. The highly volatile nature of naphthalene also likely explains why the measured dilution factor in the exposure tanks was only roughly one third of the nominal concentration (Table $5)$.

\subsection{Uptake of APs into the tissue of PW exposed fish}

Analysis of the AP levels in cod tissue showed a dose related uptake. For yolk-sac larvae the AP concentration was measured in a pooled sample made up of approximately 2000 individual larvae (approx. wet weight $1 \mathrm{~g}$ ) from all the parallel exposure tanks and sampled 3 dph. For early juveniles (sampled $78 \mathrm{dph}$ ) the AP analysis was performed on a pooled sample consisting of 10 individuals (approx. wet weight $1 \mathrm{~g}$ ) from each of the 3 parallel exposure tanks. For late juveniles (sampled in September 2004) the AP analysis was performed on liver samples from 5 individual fish from each of the two parallel exposure tanks. Our analysis clearly showed that the fish in the H-PW group had taken up the highest levels of APs. Detectable levels of APs were also seen on the M-PW group, but the levels present of the LPW group were not significantly different from the background levels found in the fish maintained in normal seawater (Figure 3A-C). 
In addition, there were clear differences in the levels of APs found in the different developmental stages. The average bioconcentration factor (BCF) for each species of AP $\left(C_{2^{-}}\right.$

$C_{5}$ ) at each developmental stage (where BCF $=A P$ concentration ( $\mu \mathrm{kg}^{-1}$ wet weight) in

tissue/AP concentration ( $\mu \mathrm{g} \mathrm{I}^{-1}$ ) in seawater) was also calculated. There was a notably higher

BCF in the yolk-sac larvae compared to the early and late juveniles for the short chain APs.

The average $\mathrm{BCF}$ for $\mathrm{C}_{2}$ phenols ( 9 different isomers) was 12 for the yolk-sac larvae, 2 for the early juveniles, and 0.6 for late juveniles. A similar pattern was also seen for the C3 phenols (10 different isomers), but not for the C4 (10 different isomers) or for the C5 phenols (6 different isomers) (Table 6).

\subsection{Effects of PW on cod embryos and yolk sac larvae}

The effects of PW on cod eggs and embryos were studied both in multi-well dishes apparent effect on survival or hatching success (an average of between 30-35\% hatched in all treatment groups) of cod eggs in experiments 1 and experiment $2 \mathrm{~A}$ (Figure 4 and data not shown). However, $100 \%$ of the embryos and newly hatched larvae exposed to H-PW (1\% PW) in the Nunc trays (experiment 1) lacked pigmentation (Figure 5), and a similar lack of pigmentation was also observed in the larvae exposed to H-PW in the tanks (experiment 2A). time points had apparently normal pigmentation. 
359

360

361

362

363

364

365

366

367

368

369

370

371

372

373

374

375

376

377

378

379

380

381

Experiment 1 also revealed a large difference in egg quality between the 5 different spawning pairs (SP). Each individual egg was inspected microscopically a total of 5 times up to $3 \mathrm{dph}$ and the percentage of visible deformities resulting in death were recorded. While one pair (SP5) demonstrated an average deformity rate of only $10 \%$, one pair (SP3) had an average deformity rate of approximately $60 \%$. However, there was no increase in the rate of embryo mortality as a result of the PW treatment (Figure 4).

\subsection{Effects of PW on larvae and early juveniles}

The larvae exposed to the highest concentration of PW (H-PW) showed clear effects: just after start-feeding the larvae were still noticeably less pigmented and the stomach was often empty or contained only a small amount of food (Figure 6). Interestingly, many larvae in the H-PW group appeared to have deformed jaws (Figures 5 and 6), and this may partly explain why these larvae are unable to feed efficiently.

At 19 dph large numbers of the larvae in the H-PW group died. This corresponds with the time of death observed in all the unfed groups. Therefore, exposure to $1 \% \mathrm{PW}$ adversely affected the ability of cod larvae to begin feeding, and most larvae died of starvation. At the end of the larval exposure regimen described in Experiment 2A (in June 2004) the surviving fish in each of the three parallel tanks of the H-PW group were counted. In one tank no fish survived and in the other two tanks only 12 and 15 fish survived, respectively. In the unexposed control group $(U)$ the number of surviving fish in each of the three parallel tanks was 693,561 , and 440 respectively. The percentage survival of the unexposed fish (U) was, therefore, slightly less than $10 \%$ (Figure 7). This enormous level of mortality and relatively 
382

383

384

385

386

387

388

389

390

391

392

393

394

395

396

397

398

399

400

401

402

403

404

low percentage survival is a normal feature of development in batch spawners such as cod, that release millions of eggs every 3 to 4 days during the spawning period (Kristiansen et al., 1997). The percentage survival in the L-PW, M-PW, and $E_{2}$ treatment groups was slightly lower than the $U$ group, but the differences observed were not significant (Figure 7).

At the start of experiment $2 \mathrm{~A}$ (in April) the standard length of all fish was approximately 5 $\mathrm{mm}$. At the end of the experiment (in June) the standard length ranged from 11-28 mm. Visually, the few surviving H-PW exposed fish were larger than the fish in the other groups at the end of experiment $2 \mathrm{~A}$ (data not shown). However, due to the low number of survivors in the H-PW group, statistical significance could not be shown. This suggests that there has been a selective mortality and density dependent growth in the H-PW exposed group. No differences in growth were found in any of the other groups.

After the exposure ended (in June 2004) the surviving fish were transferred to clean seawater and growth and survival was monitored until December 2004. There were no significant differences in mortality throughout the experiment (which was less than $10 \%$ in all groups from June to December 2004). But the fish in the M-PW $(19.2 \pm 1.9 \mathrm{~mm})$ and L-PW $(19.4 \pm 1.9 \mathrm{~mm})$ groups were slightly smaller than the $E_{2}(20.0 \pm 1.9 \mathrm{~mm})$ and $U(19.9 \pm 2.0$ $\mathrm{mm}$ ) groups at the end of the experiment (in December 2004). However, we feel that this small difference in growth (which is statistically significant) has little if any biological relevance, and the statistical significance is partly due to the large number of observations ( $n=200$ in each group). 
405

406

407

408

409

410

411

412

413

414

415

416

417

418

419

420

421

422

423

424

425

426

\subsection{Effects on cod juveniles exposed to PW between 3-6 months of age}

The percentage survival during experiment 2B was between $86-91 \%$, and there was no significant difference between any of the groups (data not shown). There was also no significant difference in the growth rate of the unexposed fish (U) and any of the PW exposed groups (Figure 8). $E_{2}$ on the other hand, had a huge effect on growth. At the end of the exposure regimen (in September 2004) the average weight of the $E_{2}$ exposed fish was only $43 \%$ of the average weight of the unexposed fish. This difference in weight was still evident in December after the fish had been kept in normal seawater for nine weeks (Figure 8).

\subsection{Expression of Vtg and CYP1A}

A significant induction of plasma Vtg levels in cod treated with $\mathrm{H}-\mathrm{PW}$ and $\mathrm{E}_{2}$ was observed (Figure 9A). In the unexposed fish (U) and the L-PW, and M-PW groups Vtg concentrations ranged from 8-14 $\mathrm{ng} \mathrm{ml}^{-1}$. In the H-PW group the Vtg concentration was $5 \mathrm{mg} \mathrm{ml}^{-1}$, and in the $E_{2}$ treated group $150 \mathrm{mg} \mathrm{ml}^{-1}$. Therefore, the Vtg concentration in the plasma of $\mathrm{H}-\mathrm{PW}$ and $\mathrm{E}_{2}$ treated fish is $0.5 \times 10^{6}-1 \times 10^{6}$ times greater than the levels in the plasma of unexposed fish. However, although the Vtg induction in the H-PW group is clearly significant, the levels in plasma are still only $3 \%$ of the levels present in the plasma of $E_{2}$ treated fish.

CYP1A levels were significantly increased in the H-PW group probably due to the PAHs in the PW. Levels of CYP1A in cod liver were significantly down-regulated following $E_{2}$ exposure (Figure 9B). 


\section{Discussion}

\subsection{PW exposure and rationale behind the experimental design}

The exposure experiments described here were performed using real produced water, collected immediately prior to discharge, from the Oseberg $\mathrm{C}$ oil production platform (StatoilHydro, Norway) located in the Norwegian sector of the North Sea. The advantage of using real produced water is that it more closely represents the complex mixture of chemical components (both known and unknown) that are discharged into the sea from oil platforms. The PW was transported to shore in $1000 \mathrm{~L}$ polyethylene (PE) containers and was then aliquoted into $25 \mathrm{~L} \mathrm{PE}$ containers and frozen at $-30^{\circ} \mathrm{C}$. The PW was flushed with air for 5 minutes before freezing and after thawing in order to remove the highly toxic hydrogen sulphide gas $\left(\mathrm{H}_{2} \mathrm{~S}\right)$. A similar procedure has recently been used to study the effects of PW on adult cod (Sundt et al., 2009). However, the chemical makeup of PW is not stable and our treatment would be expected to alter the composition. Flushing with air will likely remove the most volatile components like benzene, toluene, ethylbenzene, and xylenes (BTEX). These compounds will also likely evaporate very quickly after the PW is released into the sea. Importantly, our analysis showed that the concentration of the AP fraction remains stable over time and throughout at least one freezing and thawing cycle (Figure 2). Furthermore, our analysis of the water chemistry during the actual exposure experiments showed the presence of a clear gradient in the AP concentration between the H-PW, M-PW and L-PW groups. Moreover, the measured AP concentrations were very close to the nominal concentrations specified in the experimental design $(1 \%, 0.1 \%$, and $0.01 \%$ PW, respectively) (Table 5). 


\subsection{Uptake of APs into fish tissues}

452

453

454

455

456

457

The range of bioconcentration factors (BCF) observed in this study was similar to those that have been reported previously (Servos, 1999). In addition, our results showed that bioaccumulation was dependent on the developmental stage of the fish. Newly hatched yolk sac larvae had a higher BCF of short chain APs $\left(C_{2} A P, C_{3} A P\right)$ compared with early and late juveniles. This may be partly explained by the fact that yolk sac larvae have a higher surface area to weight ratio than later developmental stages (Petersen and Kristensen, 1998). However, it is also likely that the detoxification enzyme system is less well developed in newly hatched cod, as has been shown to be the case for the cytochrome P-450 system (Goksøyr et al., 1988). The relative lack of short chain APs ( $C_{2} A P$ and $\left.C_{3} A P\right)$ in the liver tissue of late juveniles supports the theory that the detoxification enzyme system is much more developed at this later stage. Generally, fish are quite efficient at metabolizing APs, mainly by phase II enzymes that conjugate intact APs to their corresponding glucuronides (FerreiraLeach and Hill, 2000).

\subsection{Effects of PW on cod embryos}

The concentrations of PW used in this study (up to $1 \%$ in the H-PW group) were not acutely toxic to cod embryos. Although there was no increase in lethal malformations after PW exposure, several sub-lethal effects were noted. Embryos exposed to PW failed to develop pigmentation at the same time as embryos incubated in clean seawater. This effect on pigmentation has been observed previously in marine embryos exposed to oil-related hydrocarbons (Falk-Petersen et al., 1985; Paine et al., 1992). A similar effect is seen in 
zebrafish (Danio rerio) embryos treated with 1-phenyl-2-thiourea (PTU). PTU is used routinely by zebrafish researchers to inhibit pigmentation (Karlsson et al., 2001). This compound inhibits melanogenesis by reducing the actively of the tyrosinase enzyme that converts tyrosine into melanin. Interestingly, it has also been shown that PTU is a weak activator of the aryl hydrocarbon receptor signaling pathway and induces weak transcription of CYP1A1 in zebrafish embryos (Wang et al., 2004). PTU has also been suggested to block production of thyroid hormone in developing zebrafish (Elsalini and Rohr, 2003). These effects have also been seen after exposure of fish embryos to oil hydrocarbons (Alkindi et al., 1996; Stephens et al., 1997; Billiard et al., 2008).

During vertebrate embryogenesis melanoblasts migrate from the neural crest and out into the developing tissue where they ultimately develop into mature melanocytes. This migration is normally a tightly controlled process, but the cellular signals that direct this migration are not well understood (Sulaimon and Kitchell, 2003). It has been suggested that abnormal development and migration of neural crest derived melanocytes may be a highly sensitive indicator of exposure to estrogenic contaminants in the environment (Bevan et al., 2003; Bevan et al., 2006). Clearly, more research on the effects of PW on the development of pigmentation and other developmental process is needed.

\subsection{Effects of PW on cod larvae and early juveniles}

Our findings strongly suggest that exposure to $1 \% \mathrm{PW}$ prevents the larvae from beginning to feed on their own, leading to death by starvation. The results presented here are also in agreement with our own earlier studies that showed that yolk sac larvae exposed to $1.5 \%$ 
496

497

498

499

500

501

502

503

504

505

506

507

508

509

510

511

512

513

514

PW for five days also failed to begin feeding on their own and died of starvation (unpublished observations). No apparent effects on survival and growth were seen in either the M-PW or L-PW exposed fish.

Larvae exposed to $1.5 \%$ PW show reduced swimming ability and at PW concentrations higher than $4 \%$ they go into narcosis and became unresponsive to stimuli (unpublished observations). This narcotic effect may explain why the larvae are not able to startfeed. Alternatively, the inability to startfeed could also be explained by the increased incidence of lower jaw deformities seen in larvae exposed to 1\% PW. Lower jaw deformities are a well characterised effect of exposure to oil compounds (Tilseth et al., 1984; Pollino and Holdway, 2002; Carls et al., 1999; Heintz et al., 1999; Debruyn et al., 2007).

Our own unpublished observations, suggesting a narcotic effect, are in agreement with earlier work on the effects of PW exposure. In one such study, turbot (Scopthalmus maximus) larvae were exposed to concentrations of PW ranging from $0.001 \%$ to $1 \%$ for a 6 week period early in development (from $53 \mathrm{dph}$ ) (Stephens et al., 2000). The authors reported no increases in mortality in any of the exposure groups but found a reduction in the swimming activity of larvae exposed to $1 \%$ PW. Larvae exposed to $0.1 \%$ and $1 \%$ PW showed changes in the ultrastructure of the cell membranes of the gills which could result in a reduced ability to take up oxygen. In addition, numerous other signs of chronic stress were observed, including increased levels of cortisol and cytochrome P450, and increased activities of CYP1A and 7-ethoxyresorufin-O-deethylase (EROD) (Stephens et al., 2000). 
519

520

521

522

523

524

525

526

527

528

529

530

531

532

533

534

535

536

537

538

539

540

541

Similarly, a reduction on growth was also observed in cod and herring (Clupea harengus) cultivated in a mesocosmos system and exposed to PW diluted 400-800 times (Gamble et al., 1987). A tenfold increase in the cytochrome P450 activity in herring larvae exposed to PW was also reported, indicating an increase in the metabolism of hydrocarbons. In addition, cod larvae exposed to the water soluble fraction (WSF) of crude oil displayed a decreased ability to begin feeding. This effect was observed at a total hydrocarbon concentration (THC) of $250 \mu \mathrm{g} \mathrm{I} \mathrm{I}^{-1}$, a THC that corresponds to approximately $1 \% \mathrm{PW}$, assuming a typical THC of 20 $\mathrm{mg} \mathrm{l}^{-1}$ (Tilseth et al., 1984).

Concentrations of PW above $1 \%$ prevent cod larvae from beginning to feed on their own. However, although the presence of APs in the water during the PW exposure and bioaccumulation of APs in the fish was clearly shown, PW contains many other compounds which likely also contribute to the toxicity. The total PAH concentration in the H-PW tanks was approximately $2 \mu \mathrm{g} \mathrm{I}^{-1}$. From the literature the lowest observed effect concentrations (LOEC) of PAHs on fish larvae are reported to range from 1-23 $\mu \mathrm{g} \mathrm{I}^{-1}$ (reviewed in (Carls et al., 2008). In addition to APs and PAHs, PW also contains a large "hump" of unresolved complex mixture (UCM), which is composed of a large number of unknown compounds that likely also contribute to the toxicity (Neff et al., 2000; Rowland et al., 2001; Booth et al., 2007; Melbye et al., 2009).

\subsection{Effects of PW on cod juveniles}

Cod at later developmental stages (after metamorphosis) appear to be more robust and their survival and growth are not affected by exposure to PW (up to $1 \%$ ). Plasma and liver 
542

543

544

545

546

547

548

tissue from cod juveniles was investigated for expression of two well known biomarkers, Vtg and CYP1A, respectively. These biomarker studies showed a significant induction of CYP1A in the livers of cod in the H-PW group (no effect was found in the M-PW or L-PW groups). Upregulation of CYP1A is a marker for an increase in PAH metabolism (Billiard et al., 2002; Whyte et al., 2000). Vtg was also up-regulated in the fish exposed to H-PW. Vtg is a biomarker that is up-regulated after exposure to oestrogen and other oestrogenic chemicals (Rotchell and Ostrander, 2003). Although the Vtg up-regulation in the H-PW group was only $3 \%$ of that observed in the $E_{2}$ treated fish (Figure 9), it is still a clear indication that PW is a potent source of oestrogenic compounds.

Livers from the cod juveniles contain approximately $20 \mu \mathrm{g} \mathrm{kg}^{-1}$ of $C_{2}-C_{5}$ APs (Figure $3 C$ ). Until recently, it was the release of long chain APs (octylphenol and nonylphenol) into the environment that was considered to be of most concern, as they were thought to be the most potent agonists of the oestrogen receptor (ER). However, Tollefsen and Nilsen (2008) have now shown that a large spectrum of AP isomers, including short chain APs, can act as ER agonists. Previous in vitro studies have also shown that PW contains oestrogenic compounds, and most studies have focussed on the well known oestrogenic effects of APs (Thomas et al., 2004a; Thomas et al., 2004b; Tollefsen et al., 2007). However, PW contains many unknown compounds that might have oestrogenic effects. For example, napthenic acids present in PW can function as xeno-estrogens (Thomas et al., 2009). Many laboratories, including our own, are currently working towards a better understanding of the mechanisms behind the effects of PW in fish. For example, material from this study has been analysed using proteomics in order to search for new biomarkers, and changes in the larval 
protein profile were observed even at the lowest PW concentration (0.001\%) (BohneKjersem et al., 2010). Several reports have also been published which have used microarray analysis to study the effects of PW at the mRNA level (Olsvik et al., 2007; Holth et al., 2008).

\subsection{Effects of $E_{2}$ exposure on the early life stages of cod.}

Severe effects were observed in the cod that had been exposed to $E_{2}$, but different effects were seen depending on the developmental stage of the fish at the time of exposure. In late juveniles, $E_{2}$ inhibited growth by more than $50 \%$ (Expt. 2B), but no effect on growth was seen in fish that had been exposed to $E_{2}$ during the embryo and larval stages (Expt. 2A). Previous studies with tilapia (Oreochromis niloticus) have shown similar growth-inhibiting effects of oestrogens ( $E_{2}$ and $17 \alpha$-ethinylestradiol). Oestrogen exposure produced significant changes in the expression of insulin-like growth factor I (IGF-I) mRNA in the liver, and also of IGF-I and growth hormone (GH) mRNA in the brain (Shved et al., 2007; Davis et al., 2008; Shved et al., 2008).

The biomarker analysis of cod plasma (from Expt. 2B) showed an enormous induction of Vtg in the plasma of $E_{2}$ treated fish. These observations are in agreement with our own previously published work, which showed that Vtg levels were induced to extreme levels in adult male cod following $E_{2}$ treatment (Meier et al., 2007). $E_{2}$ also strongly down-regulated expression of CYP1A via a mechanism that likely involves crosstalk between the ER and the AhR (Safe et al., 2000; Navas and Segner, 2001).

\subsection{Environmental implications of our results compared to the situation in the field}


588

589

590

591

592

593

594

595

596

597

598

599

600

601

602

603

604

605

606

607

608

609

610

Field studies conducted with fish, mussels, and passive samplers in cages have shown that it is possible to detect an increased uptake of PAHs and APs up to several kilometres from the platform (Hylland et al., 2008; Durell et al., 2006; Johnsen and Røe, 1998; Tollefsen et al., 2005; Harman et al., 2009). Biomarker analyses have also shown that fish held in cages close to the PW discharge outlet show a small but detectable induction of Vtg and CYP1A (King et al., 2005; Scott et al., 2006a; Zhu et al., 2008). In addition, a size dependent increase in the levels of Vtg in plasma has been found in wild male cod from the North Sea (Scott et al., 2006b). Scott et al (2006b) suggest that oestrogenic exposure may originate from compounds that are biomagnified up through the food chain, but their results also showed that cod with increased Vtg levels were not only found in areas with high oil production activity.

It is important to point out that no definite proof that wild fish caught between North Sea oil fields are adversely affected by PW has been found (Grøsvik et al., 2007; Hylland et al., 2008). On the other hand, wild haddock caught in the Tampen region (an area with high oil production activity) showed increased levels of PAH metabolites in the bile and an increase in the occurrence of DNA adducts in the liver when compared with haddock caught in the Egersund Bank (an area with no oil activity). No similar adverse effects were found in cod or saithe (Pollachius virens) caught in the Tampen region (Hylland et al., 2006; Grøsvik et al., 2007).

Results presented here show that the cod yolk sac larvae stage were the most sensitive to the harmful effects of PW. Our data demonstrate that the lowest observable effect 
611 concentration (LOEC) on yolk sac larvae is between $0.1 \%$ and $1 \% \mathrm{PW}$. But due to the dilution

612 factor this concentration can only be expected to be found very close to oil platforms. After

613 PW is discharged into the sea it is quickly diluted and the bioactive compounds will most

614 likely be diluted to a concentration that does not produce any large scale harmful biological

615 effects (Durell et al., 2006; Neff et al., 2006).

616

617 However, due to the sheer volume discharged into the North Sea (and discharges are

618 forecast to continue rising until at least 2012-2014), PW is still considered to be a major

619 source of environmental pollution. The concerns about PW have led the Norwegian

620 government to enforce a strict "zero-discharge" policy for all oil exploration activities in the

621 Norwegian Arctic areas. 
623 This work was supported by the Norwegian Research Council, NFR project no. 141213/720

624 and NFR 159189/720. Torill Røe Utvik, Statoil Hydro is acknowledged for supplying the

625 project with PW from the Oseberg C field. The authors would also like to thank Dr. Anders

626 Thorsen for photographing the cod larvae and Frank Midtøy, Turid Solbakken, Kjersti Eline

627 Larsen, Vibeke Lokøy, Julie Skadal, and Anders Fuglevik for technical assistance.

628 
629

630

631

632

633

634

635

636

637

638

639

640

641

642

643

644

645

646

647

648

649

650

\section{Figure legends}

\section{Figure 1}

Schematic representation of experiments 1, 2A and 2B. Experiment 1 was conducted in 24well trays and ended on 16/04 ( $3 \mathrm{dph}$ ). Fish in experiment $2 \mathrm{~A}$ were maintained in $100 \mathrm{~L}$ tanks during the PW exposure phase. At the end of the exposure, 200 randomly selected fish from the $M-P W, L-P W, U$ and $E_{2}$ treatment groups were transferred to four $500 \mathrm{~L}$ tanks containing normal seawater, where they were maintained till December 2004. The fish in the H-PW group died during the exposure, so we were unable to study these fish further $\left({ }^{*}\right)$. In experiment $2 \mathrm{~B}$, the fish were maintained in $500 \mathrm{~L}$ tanks throughout the experiment. The fish were exposed to $\mathrm{PW}$ or $\mathrm{E}_{2}$ for 78 days, after which they were maintained in normal seawater until December 2004. In the schematic diagram above filled boxes indicate exposure to PW or $E_{2}$, while open boxes indicate normal seawater. The time frame of the experiment is shown at the top, where the months of the year are indicated by capital letters. Fertilization (F) and three days post hatch ( $3 \mathrm{dph}$ ) are marked above the relevant dates. Dashed lines indicate the beginning and end of experiments and exposure periods (see Materials and Methods for a detailed description). The total number of fish used at each stage of the experiments is shown by the first line of numbers under the exposure regimen. The second line of text indicates the number of parallel tanks and their volume (or wells for Expt. 1) within the brackets, and the number of groups is indicated outside the brackets.

\section{Figure 2}


651

652 as the sum of all isomers at each molecular size.

653

654

655

656

657

658

659

660

661

662

663

664

665

666

667

668

669

670

671

672

673

\section{Figure 3} parallel tanks $(n=10)$.

\section{Figure 4} concentrations used in experiments $2 \mathrm{~A}$ and $2 \mathrm{~B}$.

\section{Figure 5}

Stability of the AP concentrations $\left(\mu \mathrm{gl}^{-1}\right)$ in the undiluted PW over time. The results are given

Tissue concentration of APs ( $\mu \mathrm{g} \mathrm{kg}^{-1}$ wet weight) in yolk sac larvae (A), early juveniles (B), and juveniles (C). The results are given as the sum of all isomers at each molecular size. For yolk sac larvae measurements were performed on only one sample $(n=1)$ pooled from each of the three parallel tanks corresponding to approximately 2000 larvae ( $1 \mathrm{~g}$ of tissue, wet weight). For early juveniles, measurements were performed on one sample from each of the three parallel tanks $(n=3)$. Each sample was made up of ten individual fish ( $1 \mathrm{~g}$ of tissue, wet weight). Results are shown as the average \pm SD. For juveniles the measurements were performed on approximately $0.5 \mathrm{~g}$ (wet weight) of liver from 5 individual fish from each of 2

Percentage of lethal deformities seen throughout the entire embryo stage in experiment 1. Eggs from each of the 5 spawning pairs (SP1-5) were incubated individually in the wells of 24 well plates (4 parallel plates were analysed for each treatment) filled with the same PW

Representative larvae (4 dph) from the $U(A)$ and H-PW (B) groups following exposure to PW at the embryo stage. The average length of the larvae at $4 \mathrm{dph}$ was $4.5 \mathrm{~mm}$. The lack of 
674 pigment and the jaw deformation can clearly be seen on the larvae from the H-PW group.

675 Pictures were retouched in Adobe Photoshop CS4. The clone stamp brush was used to 676 remove foreign particles and contrast was increased using the levels function. As a final 677 retouch sharpening was performed using the unsharp mask filter.

678

679

680

681

682

683

684

685

686

687

688

689

690

691

692

693

694

695

\section{Figure 6}

Representative larvae (14 dph) from the $U(A)$ and H-PW (B) groups. The average length of larvae at $14 \mathrm{dph}$ was $5 \mathrm{~mm}$. An arrow shows the stomach. Zooplankton can clearly be seen in the stomach of the larvae from the $U$ group $(A)$, but not in the stomach of the larvae from the H-PW group (B). The larvae from the H-PW group also has deformed jaws.

\section{Figure 7}

Survival and growth in Experiment 2A. Survival after 90 days of exposure during the egg and larval stage.

\section{Figure 8}

Growth in Experiment 2B. Growth of juveniles, measured as total length (cm), both during and after exposure (July-December).

\section{Figure 9}

A. Concentration of Vtg in serum as measured by ELISA. B. Levels of CYP1A in liver as measured by ELISA. 
696

697

698

699

700

701

702

703

704

705

706

707

708

709

710

711

712

713

714

715

716

717

Reference List

Alkindi, A.Y., Brown, J.A., Waring, C.P., and Collins, J.E., 1996. Endocrine, osmoregulatory, respiratory and haematological parameters in flounder exposed to the water soluble fraction of crude oil. Journal of Fish Biology 49, 1291-1305.

Arukwe, A., 2005. Modulation of brain steroidogenesis by affecting transcriptional changes of steroidogenic acute regulatory (StAR) protein and cholesterol side chain cleavage (P450scC) in juvenile Atlantic salmon (Salmo salar) is a novel aspect of nonylphenol toxicity. Environmental Science \& Technology 39, 9791-9798.

Arukwe, A. and Goksøyr, A., 1998. Xenobiotics, xenoestrogens and reproduction disturbances in fish. SARSIA 83, 225-241.

Bevan, C.L., Porter, D.M., Prasad, A., Howard, M.J., and Henderson, L.P., 2003. Environmental estrogens alter early development in Xenopus laevis. Environmental Health Perspectives 111, 488496.

Bevan, C.L., Porter, D.M., Schumann, C.R., Bryleva, E.Y., Hendershot, T.J., Liu, H.B., Howard, M.J., and Henderson, L.P., 2006. The endocrine-disrupting compound, nonylphenol, inhibits neurotrophindependent neurite outgrowth. Endocrinology 147, 4192-4204.

Billard, R., 1992. Reproduction in rainbow trout: Sex differentiation, dynamics of gametogenesis, biology and preservation of gametes. Aquaculture 100, 263-298.

Billiard, S.M., Hahn, M.E., Franks, D.G., Peterson, R.E., Bols, N.C., and Hodson, P.V., 2002. Binding of polycyclic aromatic hydrocarbons (PAHs) to teleost aryl hydrocarbon receptors (AHRs). Comparative Biochemistry and Physiology B-Biochemistry \& Molecular Biology 133, 55-68. 
718

719

720

721

722

723

724

725

726

727

728

729

730

731

732

733

734

735

736

737

Billiard, S.M., Meyer, J.N., Wassenberg, D.M., Hodson, P.V., and Di Giulio, R.T., 2008. Nonadditive effects of PAHs on early vertebrate development: Mechanisms and implications for risk assessment. Toxicological Sciences 105, 5-23.

Blazquez, M., Zanuy, S., Carrillo, M., and Piferrer, F., 1998. Structural and functional effects of early exposure to estradiol-17 $\beta$ and $17 \alpha$-ethynylestradiol on the gonads of the gonochoristic teleost Dicentrarchus labrax. Fish Physiology and Biochemistry 18, 37-47.

Bohne-Kjersem, A., Bache, N., Meier, S., Nyhammer, G., Roepstorff, P., Sæle, O., Goksøyr, A., and Grøsvik, B.E., 2010. Biomarker candidate discovery in Atlantic cod (Gadus morhua) continuously exposed to North Sea produced water from egg to fry. Aquatic Toxicology 96, 280-289.

Boitsov, S., Meier, S., Klungsøyr, J., and Svardal, A., 2004. Gas chromatography-mass spectrometry analysis of alkylphenols in produced water from offshore oil installations as pentafluorobenzoate derivatives. Journal of Chromatography A 1059, 131-141.

Boitsov, S., Mjøs, S.A., and Meier, S., 2007. Identification of estrogen-like alkylphenols in produced water from offshore oil installations. Marine Environmental Research 64, 651-665.

Booth, A.M., Sutton, P.A., Lewis, C.A., Lewis, A.C., Scarlett, A., Chau, W., Widdows, J., and Rowland, S.J., 2007. Unresolved complex mixtures of aromatic hydrocarbons: Thousands of overlooked persistent, bioaccumulative, and toxic contaminants in mussels. Environmental Science \& Technology 41, 457-464.

Carls, M.G., Holland, L., Larsen, M., Collier, T.K., Scholz, N.L., and Incardona, J.P., 2008. Fish embryos are damaged by dissolved PAHs, not oil particles. Aquatic Toxicology 88, 121-127. 
738

739

Carls, M.G., Rice, S.D., and Hose, J.E., 1999. Sensitivity of fish embryos to weathered crude oil: Part I. Low-level exposure during incubation causes malformations, genetic damage, and mortality in larval Pacific herring (Clupea pallasi). Environmental Toxicology and Chemistry 18, 481-493.

Chiasson, M., Benfey, T.J., and Martin-Robichaud, D.J., 2008. Gonadal differentiation in Atlantic cod, Gadus Morhua L., and haddock, Melanogrammus Aeglefinus (L.). Acta Ichthyologica et Piscatoria 38, 127-133.

Davis, L.K., Pierce, A.L., Hiramatsu, N., Sullivan, C.V., Hirano, T., and Grau, E.G., 2008. Gender-specific expression of multiple estrogen receptors, growth hormone receptors, insulin-like growth factors and vitellogenins, and effects of $17 \beta$-estradiol in the male tilapia (Oreochromis mossambicus). General and Comparative Endocrinology 156, 544-551.

Debruyn, A.M.H., Wernick, B.G., Stefura, C., McDonald, B.G., Rudolph, B.L., Patterson, L., and Chapmant, P.M., 2007. In situ experimental assessment of lake whitefish development following a freshwater oil spill. Environmental Science \& Technology 41, 6983-6989.

Devlin, R.H. and Nagahama, Y., 2002. Sex determination and sex differentiation in fish: an overview of genetic, physiological, and environmental influences. Aquaculture 208, 191-364.

Durell, G.S., Utvik, T.R., Johnsen, S., Frost, T., and Neff, J.M., 2006. Oil well produced water discharges to the North Sea. Part I: Comparison of deployed mussels (Mytilus edulis), semi-permeable membrane devices, and the DREAM model predictions to estimate the dispersion of polycyclic aromatic hydrocarbons. Marine Environmental Research 62, 194-223.

Elsalini, O.A. and Rohr, K.B., 2003. Phenylthiourea disrupts thyroid function in developing zebrafish. Development Genes And Evolution 212, 593-598. 
759

760

761

762

763

764

765

766

767

768

769

770

771

772

773

774

775

776

777

Falk-Petersen, I.B., Kjørsvik, E., Lonning, S., Naley, A.M., and Sydnes, L.K., 1985. Toxic effects of hydroxylated aromatic hydrocarbons on marine embryos. SARSIA.

Ferreira-Leach, A.M.R. and Hill, E.M., 2000. Bioconcentration and metabolism of 4-tert-octylphenol in roach (Rutilus rutilus) fry. Analusis $28,789-792$.

Gamble, J.C., Davies, J.M., HAY, S.J., and Dow, F.K., 1987. Mesocosm experiments on the effects of produced water discharges from offshore oil platforms in the northern North sea. SARSIA 72, 383386.

Gimeno, S., Gerritsen, A., Bowmer, T., and Komen, H., 1996. Feminization of male carp. Nature 384, 221-222.

Gimeno, S., Komen, H., Jobling, S., Sumpter, J., and Bowmer, T., 1998. Demasculinisation of sexually mature male common carp, Cyprinus carpio, exposed to 4-tert-pentylphenol during spermatogenesis. Aquatic Toxicology 43, 93-109.

Goksøyr, A., Serigstad, B., Solberg, T.S., and Stegeman, J.J., 1988. Response of cod (Gadus morhua) larvae and juveniles to oil exposure detected with anti-cod cytochrome-P-450c IgG and anti-scup cytochrome-P-450E MAb 1-12-3. Marine Environmental Research 24, 31-35.

Gronen, S., Denslow, N., Manning, S., Barnes, S., Barnes, D., and Brouwer, M., 1999. Serum vitellogenin levels and reproductive impairment of male Japanese medaka (Oryzias latipes) exposed to 4-tert-octylphenol. Environmantal Health Perspectives 107, 385-390.

Grøsvik, B.E., Meier, S., Westrheim, K., Skarphedinsdottir, H., Liewenborg, B., Balk, L., and Klungsøyr, J., 2007. Monitoring of the environmental condition in the water column 2005: Oil hydrocarbons in fish from Norwegian waters. IMR report, Bergen, Norway. 
780

781

782

783

784

785

786

787

788

789

790

791

792

793

794

795

796

797

798

799

800

801

Harman, C., Thomas, K.V., Tollefsen, K.E., Meier, S., Boyum, O., and Grung, M., 2009. Monitoring the freely dissolved concentrations of polycyclic aromatic hydrocarbons (PAH) and alkylphenols (AP) around a Norwegian oil platform by holistic passive sampling. Marine Pollution Bulletin 58, 16711679.

Harris, C.A., Santos, E.M., Janbakhsh, A., Pottinger, T.G., Tyler, C.R., and Sumpter, J.P., 2001. Nonylphenol affects gonadotropin levels in the pituitary gland and plasma of female rainbow trout. Environmental Science \& Technology 35, 2909-2916.

Heintz, R.A., Short, J.W., and Rice, S.D., 1999. Sensitivity of fish embryos to weathered crude oil: Part II. Increased mortality of pink salmon (Oncorhynchus gorbuscha) embryos incubating downstream from weathered Exxon Valdez crude oil. Environmental Toxicology and Chemistry 18, 494-503.

Hendry, C.I., Martin-Robichaud, D.J., and Benfey, T.J., 2002. Gonadal sex differentiation in Atlantic halibut. Journal of Fish Biology 60, 1431-1442.

Holth, T.F., Nourizadeh-Lillabadi, R., Blaesbjerg, M., Grung, M., Holbech, H., Petersen, G.I., Alestrøm, P., and Hylland, K., 2008. Differential gene expression and biomarkers in zebrafish (Danio rerio) following exposure to produced water components. Aquatic Toxicology 90, 277-291.

Hylland, K., Beyer, J., Berntssen, M., Klungsøyr, J., Lang, T., and Balk, L., 2006. May organic pollutants affect fish populations in the North Sea? Journal of Toxicology and Environmental Health-Part ACurrent Issues 69, 125-138.

Hylland, K., Tollefsen, K.E., Ruus, A., Jonsson, G., Sundt, R.C., Sanni, S., Røe Utvik, T.I., Johnsen, S., Nilssen, I., Pinturier, L., Balk, L., Barsiene, J., Marigomez, I., Feist, S.W., and Borseth, J.F., 2008. Water column monitoring near oil installations in the North Sea 2001-2004. Marine Pollution Bulletin 56, 414-429. 
802

803

804

805

806

807

808

809

810

811

812

813

814

815

816

817

818

819

820

821

822

Ioppolo-Armanios, M.I., Alexander, R., and Kagi, R.I., 1992. Identification and analysis of $C_{0} C_{3}$ phenol in Australian crude oils. Organic Geochemistry 18, 603-609.

Jobling, S. and Sumpter, J.P., 1993. Detergent components in sewage effluent are weakly oestrogenic to fish: An in vitro study using rainbow trout (Oncorhynchus mykiss) hepatocytes. Aquatic Toxicology $27,361-372$.

Johnsen, S. and Røe, T.I., 1998. Dilution and bioavailability of produced water compounds in the northern North Sea. A combined modeling and field study. SPE 46269.Society of Petroleum Engineers, Richardson, TX 1-6.

Kang, I.J., Yokota, H., Oshima, Y., Tsuruda, Y., Hano, T., Maeda, M., Imada, N., Tadokoro, H., and Honjo, T., 2003. Effects of 4-nonylphenol on reproduction of Japanese medaka, Oryzias latipes. Environmental Toxicology and Chemistry 22, 2438-2445.

Karlsson, J., von Hofsten, J., and Olsson, P.E., 2001. Generating transparent zebrafish: A refined method to improve detection of gene expression during embryonic development. Marine Biotechnology 3, 522-527.

King, S.C., Johnson, J.E., Haasch, M.L., Ryan, D.A.J., Ahokas, J.T., and Burns, K.A., 2005. Summary results from a pilot study conducted around an oil production platform on the Northwest Shelf of Australia. Marine Pollution Bulletin 50, 1163-1172.

Kjesbu, O.S., 1989. The spawning activity of cod, gadus-morhua L. Journal of Fish Biology 34, 195-206.

Knorr, S. and Braunbeck, T., 2002. Decline in reproductive success, sex reversal, and developmental alterations in Japanese medaka (Oryzias latipes) after continuous exposure to octylphenol. Ecotoxicology and Environmental Safety 51, 187-196. 
823

824

825

826

827

828

829

830

831

832

833

834

835

836

837

838

839

840

841

842

Kristiansen, T.S., Jorstad, K.E., Ottera, H., Paulsen, O.I., and Svasand, T., 1997. Estimates of larval survival of cod by releases of genetically marked yolk-sac larvae. Journal of Fish Biology 51, 264-283.

Meier, S., Andersen, T.E., Norberg, B., Thorsen, A., Taranger, G.L., Kjesbu, O.S., Dahle, R., Morton, H.C., Klungsøyr, J., and Svardal, A., 2007. Effects of alkylphenols on the reproductive system of Atlantic cod (Gadus morhua). Aquatic Toxicology 81, 207-218.

Meier, S., Klungsøyr, J., Boitsov, S., Eide, T., and Svardal, A., 2005. Gas chromatography-mass spectrometry analysis of alkylphenols in cod (Gadus morhua) tissues as pentafluorobenzoate derivatives. Journal of Chromatography A 1062, 255-268.

Melbye, A.G., Brakstad, O.G., Hokstad, J.N., Gregersen, I.K., Hansen, B.H., Booth, A.M., Rowland, S.J., and Tollefsen, K.E., 2009. Chemical and toxicological characterization of an unresolved complex mixture-rich biodegraded crude oil. Environmental Toxicology and Chemistry 28, 1815-1824.

Miles-Richardson, S.R., Pierens, S.L., Nichols, K.M., Kramer, V.J., Snyder, E.M., Snyder, S.A., Render, J.A., Fitzgerald, S.D., and Giesy, J.P., 1999. Effects of waterborne exposure to 4-nonylphenol and nonylphenol ethoxylate on secondary sex characteristics and gonads of fathead minnows (Pimephales promelas). Environmental Research 80, S122-S137.

Navas, J.M. and Segner, H., 2001. Estrogen-mediated suppression of cytochrome P4501A (CYP1A) expression in rainbow trout hepatocytes: role of estrogen receptor. Chemico-Biological Interactions $138,285-298$.

Neff, J.M., 2002. Bioaccumulation in marine organisms. Effect of contaminants from oil well produced water. Elsevier Science Ltd, Oxford, UK. 
843

844

845

846

847

848

849

850

851

852

853

854

855

856

857

858

859

860

861

862

863

Neff, J.M., Johnsen, S., Frost, T.K., Utvik, T.I.R., and Durell, G.S., 2006. Oil well produced water discharges to the North Sea. Part II: Comparison of deployed mussels (Mytilus edulis) and the DREAM model to predict ecological risk. Marine Environmental Research 62, 224-246.

Neff, J.M., Ostazeski, S., Gardiner, W., and Stejskal, I., 2000. Effects of weathering on the toxicity of three offshore Australian crude oils and a diesel fuel to marine animals. Environmental Toxicology and Chemistry 19, 1809-1821.

Nilsen, B.M., Berg, K., and Goksøyr, A., 1998. Induction of Cytochrome P450 1A (CYP1A) in Fish: A biomarker for Environmental Pollution. in: Phillips, I.R. and Shephard, E.A. (Eds.), Methods in Molecular Biology, Vol 107: Cytochrome P450 Protocols. Humana Press Inc, Totowa, NJ, pp. 423-438.

Olsvik, P.A., Lie, K.K., Stavrum, A.K., and Meier, S., 2007. Gene-expression profiling in gill and liver of zebrafish exposed to produced water. International Journal of Environmental Analytical Chemistry $87,195-210$

Paine, M.D., Leggett, W.C., McRuer, J.K., and Frank, K.T., 1992. Effects of hibernia crude-oil on capelin (mallotus-villosus) embryos and larvae. Marine Environmental Research 33, 159-187.

Petersen, G.I. and Kristensen, P., 1998. Bioaccumulation of lipophilic substances in fish early life stages. Environmental Toxicology and Chemistry 17, 1385-1395.

Pollino, C.A. and Holdway, D.A., 2002. Toxicity testing of crude oil and related compounds using early life stages of the crimson-spotted rainbowfish (Melanotaenia fluviatilis). Ecotoxicology and Environmental Safety 52, 180-189.

Rotchell, J.M. and Ostrander, G.K., 2003. Molecular markers of endocrine disruption in aquatic organisms. Journal Of Toxicology And Environmental Health-Part B-Critical Reviews 6, 453-495. 
864

865

866

867

868

869

870

871

872

873

874

875

876

877

878

879

880

881

882

883

884

885

Rowland, S., Donkin, P., Smith, E., and Wraige, E., 2001. Aromatic hydrocarbon "humps" in the marine environment: Unrecognized toxins? Environmental Science \& Technology 35, 2640-2644.

Rye, H., Reed, M., and Ekrol, N., 1998. Sensitivity analysis and simulation of dispersed oil concentrations in the North Sea with the PROVANN model. Environmental Modeling \& Software 13, 421-429.

Safe, S., Wormke, M., and Samudio, I., 2000. Mechanisms of inhibitory aryl hydrocarbon receptorestrogen receptor crosstalk in human breast cancer cells. Journal Of Mammary Gland Biology And Neoplasia 5, 295-306.

Scott, A.P., Kristiansen, S.I., Katsiadaki, I., Thain, J., Tollefsen, K.E., Goksøyr, A., and Barry, J., $2006 a$. Assessment of Oestrogen Exposure in Cod (Gadus morhua) and Saithe (Pollachius Virens) in Relation to their Proximity to an Oilfield. in: Hylland, K., Lang, T., and Vethaak, A.D. (Eds.), Biological Effects of Contaminants in Marine Pelagic Ecosystems Society of Environmental Toxicology and Chemistry (SETAC), pp. 329-339.

Scott, A.P., Katsiadaki, I., Witthames, P.R., Hylland, K., Davies, I.M., Mclntosh, A.D., and Thain, J., 2006b. Vitellogenin in the blood plasma of male cod (Gadus morhua): A sign of oestrogenic endocrine disruption in the open sea? Marine Environmental Research 61, 149-170.

Seki, M., Yokota, H., Maeda, M., Tadokoro, H., and Kobayashi, K., 2003. Effects of 4-nonylphenol and 4-tert-octylphenol on sex differentiation and vitellogenin induction in medaka (Oryzias latipes). Environmental Toxicology and Chemistry 22, 1507-1516.

Servos, M.R., 1999. Review of the aquatic toxicity, estrogenic responses and bioaccumulation of alkylphenols and alkylphenol polyethoxylates. Water Quality Research Journal of Canada 34, 123177. 
886

887

888

889

890

891

892

893

894

895

896

897

898

899

900

901

902

903

904

905

906

Shved, N., Berishvili, G., Baroiller, J.F., Segner, H., and Reinecke, M., 2008. Environmentally relevant concentrations of 17 a-ethinylestradiol (EE2) interfere with the growth hormone (GH)/insulin-like growth factor (IGF)-I system in developing bony fish. Toxicological Sciences 106, 93-102.

Shved, N., Berishvili, G., D'Cotta, H., Baroiller, J.F., Segner, H., Eppler, E., and Reinecke, M., 2007. Ethinylestradiol differentially interferes with IGF-I in liver and extrahepatic sites during development of male and female bony fish. Journal of Endocrinology 195, 513-523.

Stephens, S.M., Alkindi, A.Y., Waring, C.P., and Brown, J.A., 1997. Corticosteroid and thyroid responses of larval and juvenile turbot exposed to the water-soluble fraction of crude oil. Journal of Fish Biology 50, 953-964.

Stephens, S.M., Frankling, S.C., Stagg, R.M., and Brown, J.A., 2000. Sub-lethal effects of exposure of juvenile turbot to oil produced water. Marine Pollution Bulletin 40, 928-937.

Sulaimon, S.S. and Kitchell, B.E., 2003. The biology of melanocytes. Veterinary Dermatology 14, 5765.

Sundt, R.C., Meier, S., Jonsson, G., Sanni, S., and Beyer, J., 2009. Development of a laboratory exposure system using marine fish to carry out realistic effect studies with produced water discharged from offshore oil production. Marine pollution bulletin 58, 1382-1388.

Tanaka, J.N. and Grizzle, J.M., 2002. Effects of nonylphenol on the gonadal differentiation of the hermaphroditic fish, Rivulus marmoratus. Aquatic Toxicology 57, 117-125.

Thomas, K.V., Balaam, J., Hurst, M.R., and Thain, J.E., 2004a. Bio-analytical and chemical characterisation of offshore produced water effluents for estrogen receptor (ER) agonists. Journal of Environmental Monitoring 6, 593-598. 
907

908

909

910

911

912

913

914

915

916

917

918

919

920

921

922

923

924

925

926

927

Thomas, K.V., Balaam, J., Hurst, M.R., and Thain, J.E., 2004b. Identification of in vitro estrogen and androgen receptor agonists in North Sea offshore produced water discharges. Environmental Toxicology and Chemistry 23, 1156-1163.

Thomas, K.V., Langford, K., Petersen, K., Smith, A.J., and Tollefsen, K.E., 2009. Effect-directed identification of naphthenic acids as important in vitro xeno-estrogens and anti-androgens in North Sea offshore produced water discharges. Environmental Science and Technology 43, 8066-8071.

Tilseth, S., Solberg, T.S., and Westrheim, K., 1984. Sublethal effects of the water-soluble fraction of Ekofisk crude oil on early larval stages of cod (Gadus morhua L.). Marine Environmental Research 11, 1-16.

Tollefsen, K.E., Bøyum, O., Kringstad, A., Finne, E.F., Odden, E., and Grung, M., 2005. Water Column Survey 2004. Water column monitoring of polar chemicals by use of POCIS passive samplers. NIVA Report: 4940-2005, Oslo, Norway.

Tollefsen, K.E., Harman, C., Smith, A., and Thomas, K.V., 2007. Estrogen receptor (ER) agonists and androgen receptor (AR) antagonists in effluents from Norwegian North Sea oil production platforms. Marine Pollution Bulletin 54, 277-283.

Tollefsen, K.E. and Nilsen, A.J., 2008. Binding of alkylphenols and alkylated non-phenolics to rainbow trout (Oncorhynchus mykiss) hepatic estrogen receptors. Ecotoxicology and Environmental Safety 69, 163-172.

van Aerle, R., Pounds, N., Hutchinson, T.H., Maddix, S., and Tyler, C.R., 2002. Window of sensitivity for the estrogenic effects of ethinylestradiol in early life-stages of fathead minnow, Pimephales promelas. Ecotoxicology 11, 423-434. 
928

929

930

931

932

933

934

935

936

937

938

939

940

941

942

943

Wang, W.D., Wang, Y., Wen, H.J., Buhler, D.R., and Hu, C.H., 2004. Phenylthiourea as a weak activator of aryl hydrocarbon receptor inhibiting 2,3,7,8-tetrachlorodibenzo-p-dioxin-induced CYP1A1 transcription in zebrafish embryo. Biochemical Pharmacology 68, 63-71.

Weber, L.P., Hill, R.L., Jr., and Janz, D.M., 2003. Developmental estrogenic exposure in zebrafish (Danio rerio): II. Histological evaluation of gametogenesis and organ toxicity. Aquatic Toxicology 63, 431-446.

Weber, L.P., Kiparissis, Y., Hwang, G.S., Niimi, A.J., Janz, D.M., and Metcalfe, C.D., 2002. Increased cellular apoptosis after chronic aqueous exposure to nonylphenol and quercetin in adult medaka (Oryzias latipes). Comparative Biochemistry and Physiology C-Pharmacology Toxicology \& Endocrinology 131, 51-59.

White, R., Jobling, S., Hoare, S.A., Sumpter, J.P., and Parker, M.G., 1994. Environmentally persistent alkylphenolic compounds are estrogenic. Endocrinology 135, 175-182.

Whyte, J.J., Jung, R.E., Schmitt, C.J., and Tillitt, D.E., 2000. Ethoxyresorufin-O-deethylase (EROD) activity in fish as a biomarker of chemical exposure. Critical Reviews in Toxicology 30, 347-570.

Yadetie, F. and Male, R., 2002. Effects of 4-nonylphenol on gene expression of pituitary hormones in juvenile Atlantic salmon (Salmo salar). Aquatic Toxicology 58, 113-129.

Yokota, H., Abe, T., Nakai, M., Murakami, H., Eto, C., and Yakabe, Y., 2005. Effects of 4-tertpentylphenol on the gene expression of P450 $11 \beta$-hydroxylase in the gonad of medaka (Oryzias latipes). Aquatic Toxicology 71, 121-132.

Zhu, S.Q., King, S.C., and Haasch, M.L., 2008. Biomarker induction in tropical fish species on the Northwest Shelf of Australia by produced formation water. Marine Environmental Research 65, 315324. 


\begin{tabular}{|ccc|}
\hline Groups & Dilution factor & Estimated distance from platform $(\mathbf{m})$ \\
\hline High $(\mathrm{H}-\mathrm{PW})$ & $1: 100(1 \%)$ & $0-50$ \\
Medium $(\mathrm{M}-\mathrm{PW})$ & $1: 1000(0.1 \%)$ & $50-1000$ \\
Low $(\mathrm{L}-\mathrm{PW})$ & $1: 10000(0.01 \%)$ & $>2000$ \\
Oestrogen $(\mathrm{E})$ & $10 \mu \mathrm{g} / \mathrm{l} 17 \beta$-estradiol & - \\
\hline
\end{tabular}

\section{Table 1}

Theoretical dilution factors and estimated environmental relevance of the PW concentrations used in this study. 


\begin{tabular}{ccc}
\hline & Average \pm SD & RSD (\%) \\
\hline Phenol & $4696 \pm 967$ & 21 \\
$\Sigma C 1$ & $7542 \pm 1334$ & 18 \\
$\Sigma C 2$ & $638 \pm 202$ & 32 \\
$\Sigma C 3$ & $216 \pm 58$ & 27 \\
$\Sigma C 4$ & $53 \pm 15$ & 28 \\
$\Sigma$ C5 & $4,7 \pm 2,5$ & 53 \\
$\Sigma C 6$ & $0,10 \pm 0,04$ & 35 \\
$\Sigma C 7$ & $0,02 \pm 0,01$ & 70 \\
$\Sigma C 8$ & $0,02 \pm 0,02$ & 96 \\
$\Sigma C 9$ & $0,09 \pm 0,05$ & 61 \\
\hline
\end{tabular}

\section{Table 2}

Average AP concentrations $(\mu \mathrm{g} / \mathrm{L})$ in the undiluted PW throughout the whole exposure period The values shown are the average concentrations of 11 separate measurements $(n=11)$ taken over a period of 154 days. The results are given as the sum of all isomers at each molecular size. 


\section{Experiment 2A}

\begin{tabular}{|c|c|c|c|c|}
\hline Concentration $\left(\mu \mathrm{g} \mathrm{I}^{-1}\right.$ & $-1)$ & L-PW & M-PW & H-PW \\
\hline Phenol & $1,04 \pm 0,00$ & $3,60 \pm 3,83$ & $3,41 \pm 3,60$ & $7,33 \pm 3,33$ \\
\hline$\Sigma C_{1}$ & $0,81 \pm 0,98$ & $0,75 \pm 0,70$ & $0,89 \pm 0,79$ & $7,41 \pm 1,63$ \\
\hline$\Sigma \mathrm{C} 2$ & $0,04 \pm 0,00$ & $0,13 \pm 0,04$ & $0,42 \pm 0,08$ & $3,90 \pm 0,20$ \\
\hline$\Sigma$ C3 & $0,04 \pm 0,02$ & $0,09 \pm 0,01$ & $0,34 \pm 0,20$ & $2,58 \pm 1,84$ \\
\hline$\Sigma \mathrm{C} 4$ & $0,015 \pm 0,007$ & $0,027 \pm 0,002$ & $0,067 \pm 0,008$ & $0,399 \pm 0,109$ \\
\hline$\Sigma$ C5 & $0,001 \pm 0,001$ & $0,003 \pm 0,002$ & $0,004 \pm 0,001$ & $0,041 \pm 0,013$ \\
\hline$\Sigma \geq \mathrm{C} 6$ & ND & ND & ND & ND \\
\hline \multicolumn{5}{|l|}{ Experiment 2B } \\
\hline Concentration $\left(\mu \mathrm{g} \mathrm{I}^{-1}\right.$ & -1 ) & L-PW & M-PW & H-PW \\
\hline Phenol & $2,96 \pm 0,66$ & $5,33 \pm 1,84$ & $10,29 \pm 6,68$ & $29,74 \pm 11,33$ \\
\hline$\Sigma C 1$ & $0,46 \pm 0,10$ & $0,81 \pm 0,49$ & $11,03 \pm 12,16$ & $51,09 \pm 24,64$ \\
\hline$\Sigma \mathrm{C} 2$ & $0,04 \pm 0,00$ & $0,08 \pm 0,03$ & $1,67 \pm 1,93$ & $9,22 \pm 3,76$ \\
\hline$\Sigma$ C3 & $0,01 \pm 0,00$ & $0,02 \pm 0,01$ & $0,27 \pm 0,18$ & $2,24 \pm 0,46$ \\
\hline$\Sigma \mathrm{C} 4$ & $0,014 \pm 0,002$ & $0,018 \pm 0,005$ & $0,060 \pm 0,033$ & $0,401 \pm 0,089$ \\
\hline$\Sigma$ C5 & $0,006 \pm 0,004$ & $0,007 \pm 0,005$ & $0,010 \pm 0,005$ & $0,034 \pm 0,007$ \\
\hline$\Sigma \geq \mathrm{C} 6$ & ND & ND & ND & ND \\
\hline
\end{tabular}

\section{Table 3}

Concentration of APs in each exposure group in experiment $2 \mathrm{~A}$ and $2 \mathrm{~B}$. Individual measurements were made on two separate days in experiment $2 A(n=2)$ and on four separate days in experiment $2 B(n=4)$. The results are given as the sum of all isomers at each molecular size. 
Experiment 2A

\begin{tabular}{|c|c|c|c|c|}
\hline Dilution factor (\%) & $\mathbf{U}$ & L-PW & M-PW & H-PW \\
\hline Phenol & $0,02 \pm 0,02$ & $0,08 \pm 0,07$ & $0,07 \pm 0,07$ & $0,17 \pm 0,03$ \\
\hline$\Sigma \mathrm{C} 1$ & $0,01 \pm 0,01$ & $0,01 \pm 0,01$ & $0,01 \pm 0,01$ & $0,11 \pm 0,05$ \\
\hline$\Sigma \mathrm{C} 2$ & $0,01 \pm 0,00$ & $0,03 \pm 0,01$ & $0,11 \pm 0,02$ & $0,97 \pm 0,08$ \\
\hline$\Sigma$ C3 & $0,02 \pm 0,00$ & $0,04 \pm 0,01$ & $0,14 \pm 0,04$ & $1,07 \pm 0,43$ \\
\hline$\Sigma \mathrm{C} 4$ & $0,03 \pm 0,02$ & $0,06 \pm 0,01$ & $0,14 \pm 0,03$ & $0,86 \pm 0,33$ \\
\hline$\Sigma$ C5 & $0,02 \pm 0,02$ & $0,09 \pm 0,08$ & $0,12 \pm 0,05$ & $1,41 \pm 0,65$ \\
\hline$\Sigma \geq \mathrm{C} 6$ & - & - & - & - \\
\hline \multicolumn{5}{|l|}{ Experiment 2B } \\
\hline Dilution factor (\%) & $\mathbf{U}$ & L-PW & M-PW & H-PW \\
\hline Phenol & $0,06 \pm 0,01$ & $0,11 \pm 0,05$ & $0,20 \pm 0,10$ & $0,60 \pm 0,24$ \\
\hline$\Sigma C 1$ & $0,01 \pm 0,00$ & $0,01 \pm 0,00$ & $0,13 \pm 0,11$ & $0,66 \pm 0,27$ \\
\hline$\Sigma \mathrm{C} 2$ & $0,00 \pm 0,00$ & $0,01 \pm 0,00$ & $0,19 \pm 0,20$ & $1,12 \pm 0,32$ \\
\hline$\Sigma$ C3 & $0,01 \pm 0,00$ & $0,01 \pm 0,01$ & $0,16 \pm 0,11$ & $1,47 \pm 0,66$ \\
\hline$\Sigma \mathrm{C} 4$ & $0,03 \pm 0,01$ & $0,04 \pm 0,02$ & $0,12 \pm 0,05$ & $0,83 \pm 0,31$ \\
\hline$\Sigma \mathrm{C} 5$ & $0,13 \pm 0,08$ & $0,15 \pm 0,10$ & $0,21 \pm 0,11$ & $0,73 \pm 0,17$ \\
\hline$\Sigma \geq \mathrm{C} 6$ & - & - & - & - \\
\hline
\end{tabular}

\section{Table 4}

Empirical dilution factors of the APs in each exposure group in experiments $2 \mathrm{~A}$ and $2 \mathrm{~B}$. The results are given as the sum of all isomers at each molecular size. 


\begin{tabular}{cccccc}
\hline & PW & H-PW & M-PW & L-PW & U \\
\hline Naphthalene & 242,9 & 0,791 & 0,173 & 0,046 & 0,020 \\
C1-naphthalene & 237,5 & 0,584 & 0,288 & 0,121 & 0,231 \\
C2-naphthalene & 97,5 & 0,303 & 0,072 & ND & ND \\
Acenaphthylene & 2,7 & ND & ND & ND & ND \\
Acenaphthene & 4,4 & ND & ND & ND & ND \\
Fluorene & 8,1 & 0,027 & 0,017 & ND & ND \\
Anthracene & 1,3 & ND & ND & ND & ND \\
Phenanthrene & 17,8 & 0,050 & 0,028 & ND & 0,032 \\
C1-Phenanthrene & 16,6 & ND & ND & ND & ND \\
Pyrene & 0,5 & ND & ND & ND & ND \\
Benz(a)anthracene & 0,8 & ND & ND & ND & ND \\
Perylene & ND & ND & ND & ND & ND \\
Dibenz(a,h)anthracene & ND & ND & ND & ND & ND \\
\hline Total PAHs & $\mathbf{6 3 0 , 1}$ & $\mathbf{1 , 8}$ & $\mathbf{0 , 6}$ & $\mathbf{0 , 2}$ & $\mathbf{0 , 3}$ \\
\hline
\end{tabular}

\section{Table 5}

Actual concentrations of PAHs ( $\mu \mathrm{g} \mathrm{I}^{-1}$ ) measured in the undiluted PW and in the H-PW, M-

PW, and L-PW exposure tanks. The background concentration of PAHs in the normal seawater used in this study was also measured $(U)$. The results shown are from one single measurement $(n=1)$ in August 2004. 


\begin{tabular}{lccc}
\hline & Yolk sac larvae & Early juveniles & Juveniles \\
\hline $\mathrm{C}_{2}$-phenol & $12 \pm 7$ & $2 \pm 2$ & $0,6 \pm 0,4$ \\
$\mathrm{C}_{3}$-phenol & $14 \pm 5$ & $10 \pm 7$ & $3 \pm 3$ \\
$\mathrm{C}_{4}$-phenol & $31 \pm 15$ & $30 \pm 23$ & $30 \pm 40$ \\
$\mathrm{C}_{5}$-phenol & $68 \pm 15$ & $74 \pm 46$ & $175 \pm 169$ \\
\hline
\end{tabular}

\section{Table 6}

Average bioconcentration factor $(\mathrm{BCF}=$ concentration in wet weight tissue/concentration in seawater) at each molecular size for the $\mathrm{H}-\mathrm{PW}$ group. For $\mathrm{C}_{2}$, the concentration of 8 isomers were measured and the average is shown in the figure. Six isomers were measured for $C_{3}$, seven for $C_{4}$ and 2 for $C_{5}$. For yolk sac larvae and early juveniles the measurements were performed on pooled samples of whole individuals. One gram of tissue was used for analysis which corresponded to approximately 2000 yolk sac larvae and 10 early juveniles. For juveniles the measurements were performed on approximately $0.5 \mathrm{~g}$ of liver from individual fish. 
Figure 1

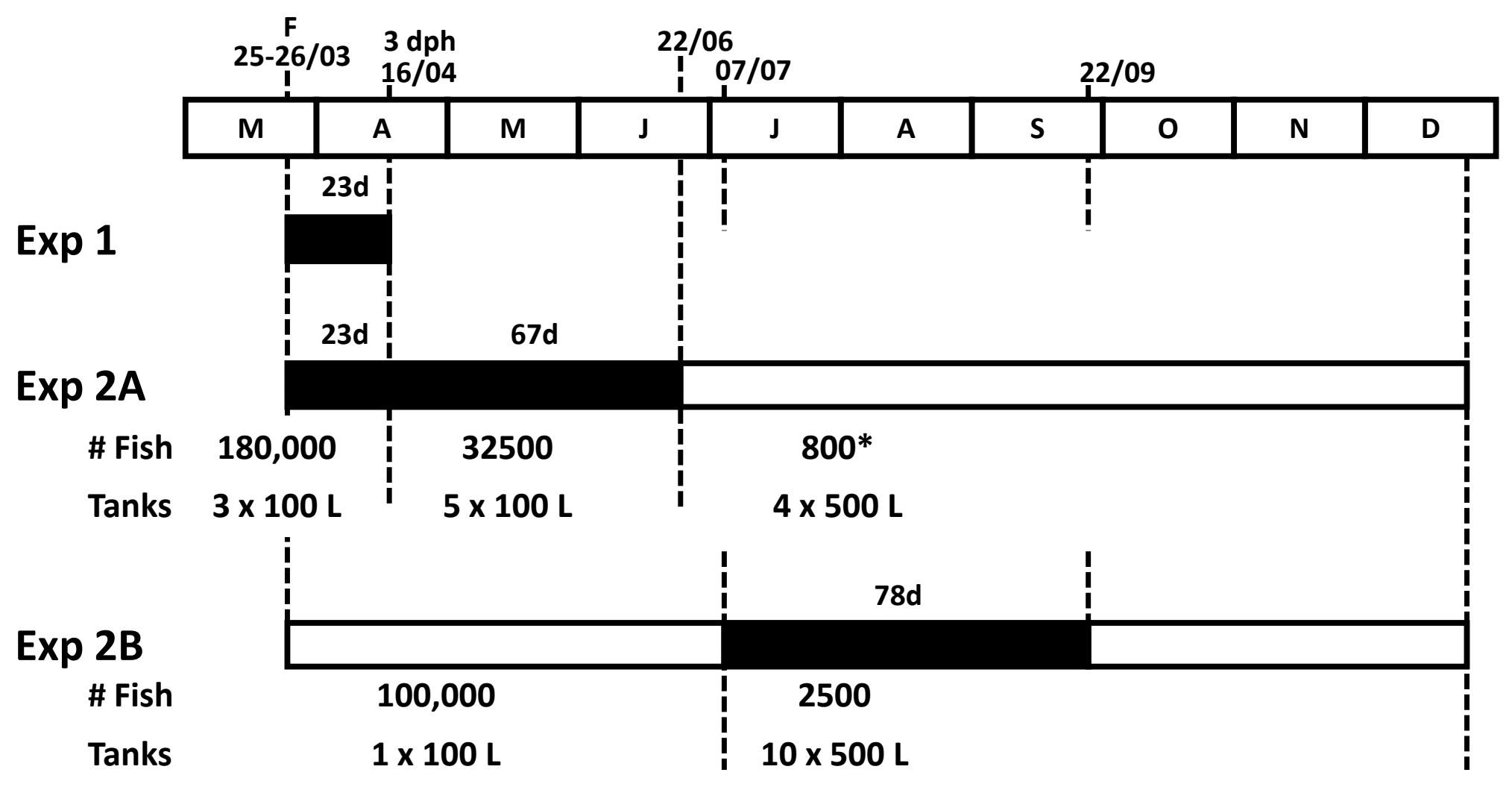




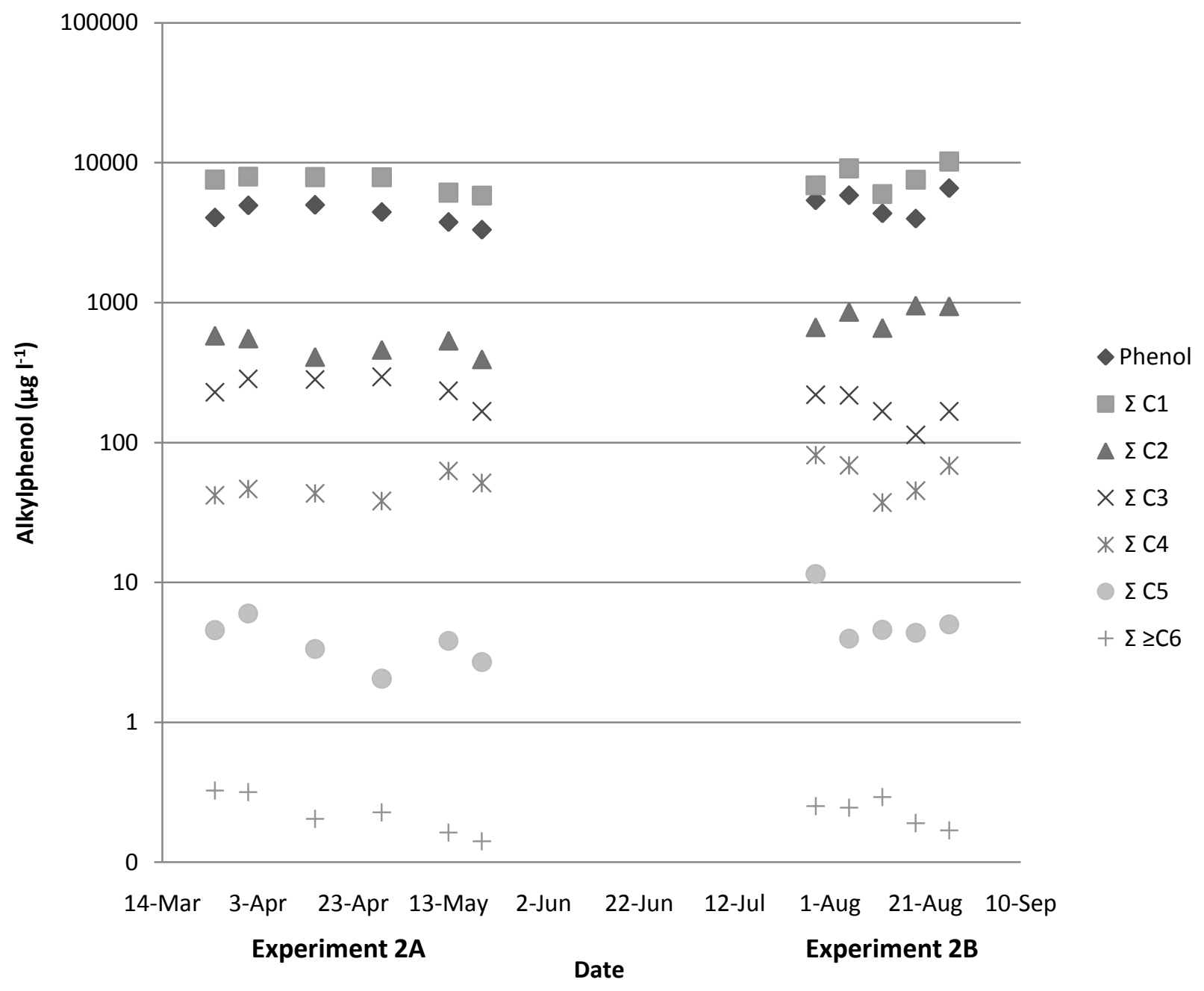



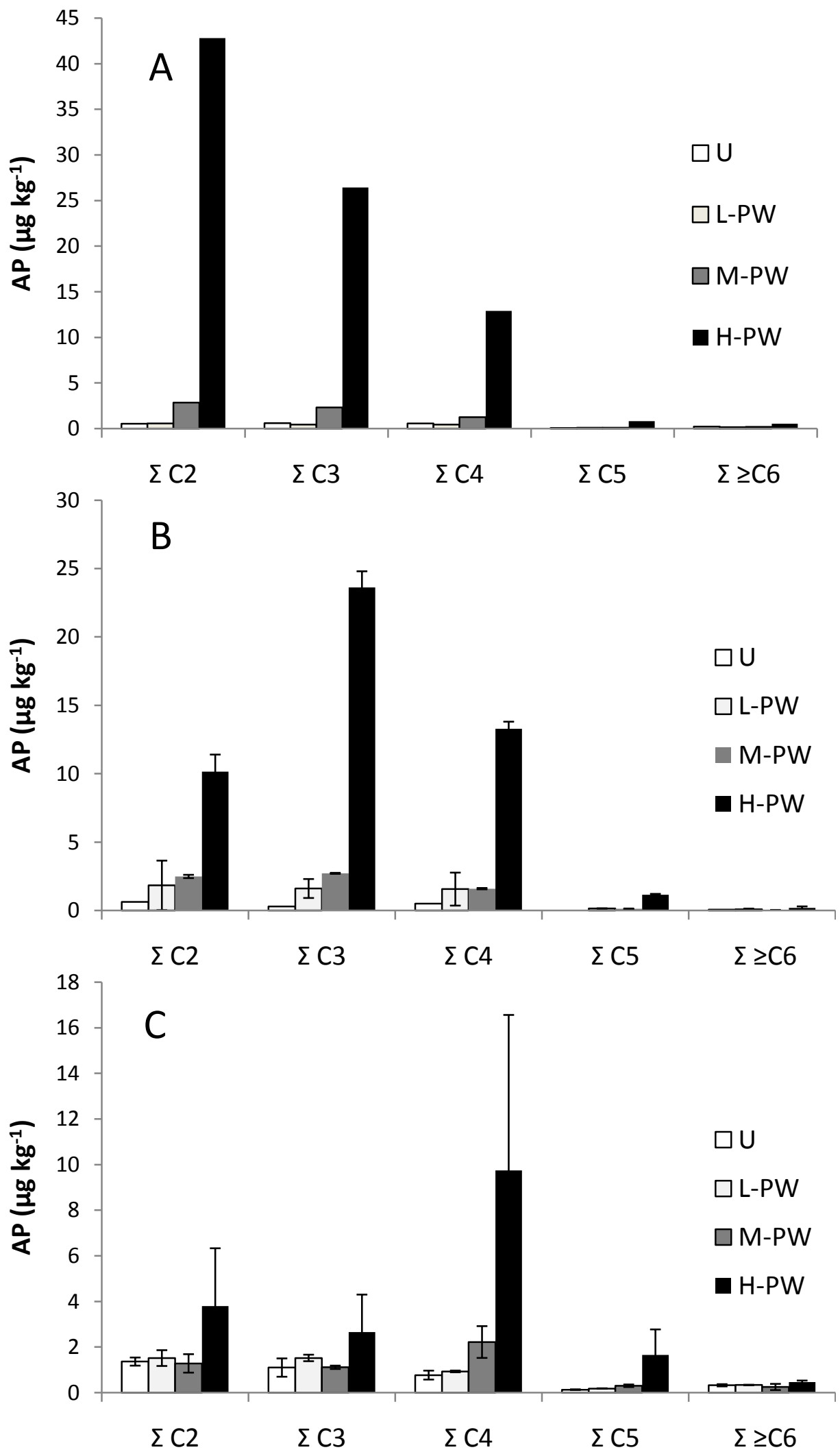


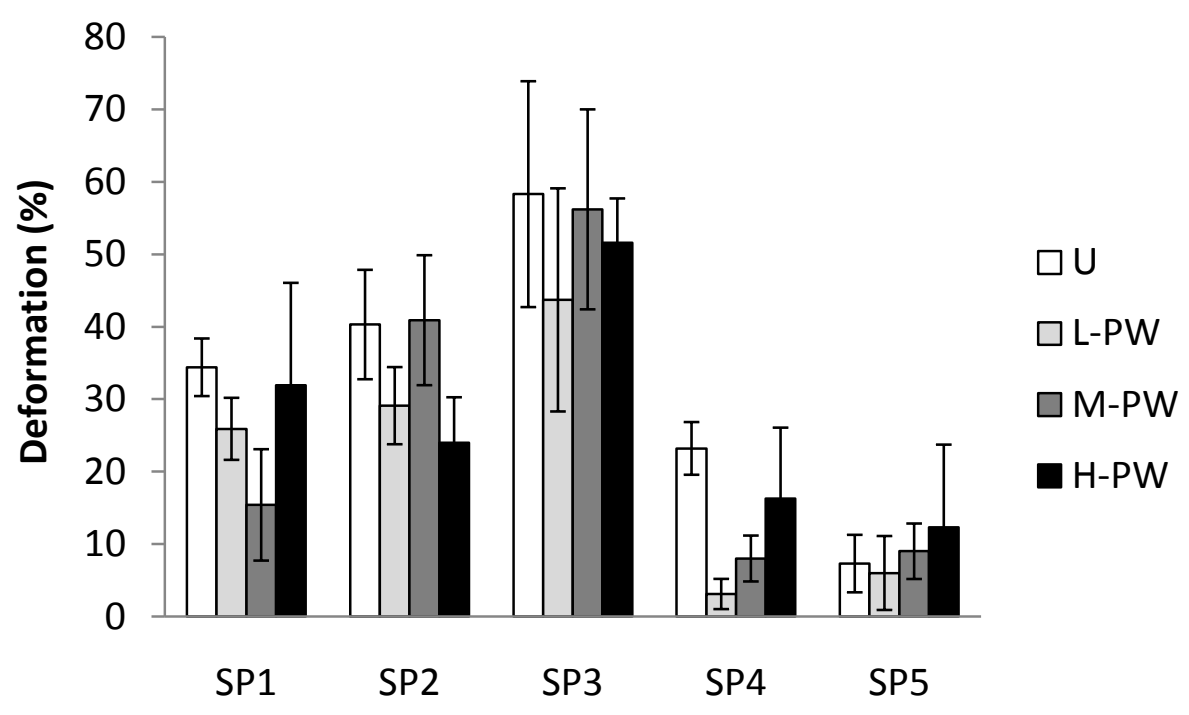



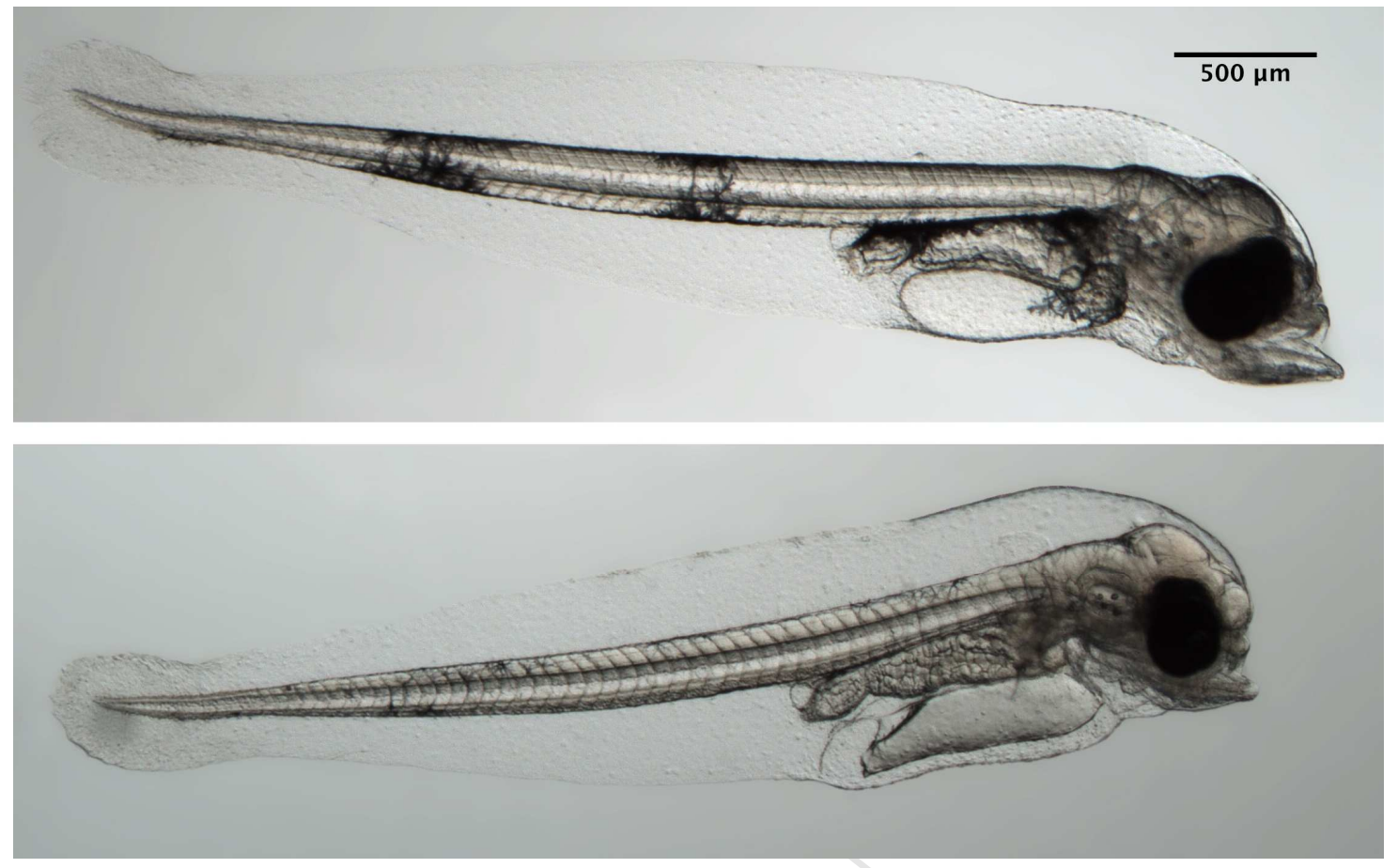


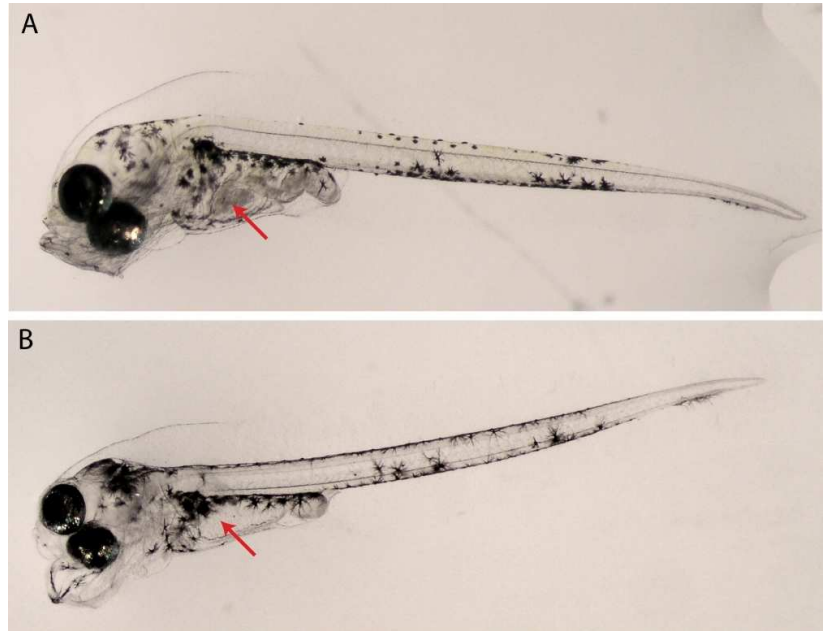




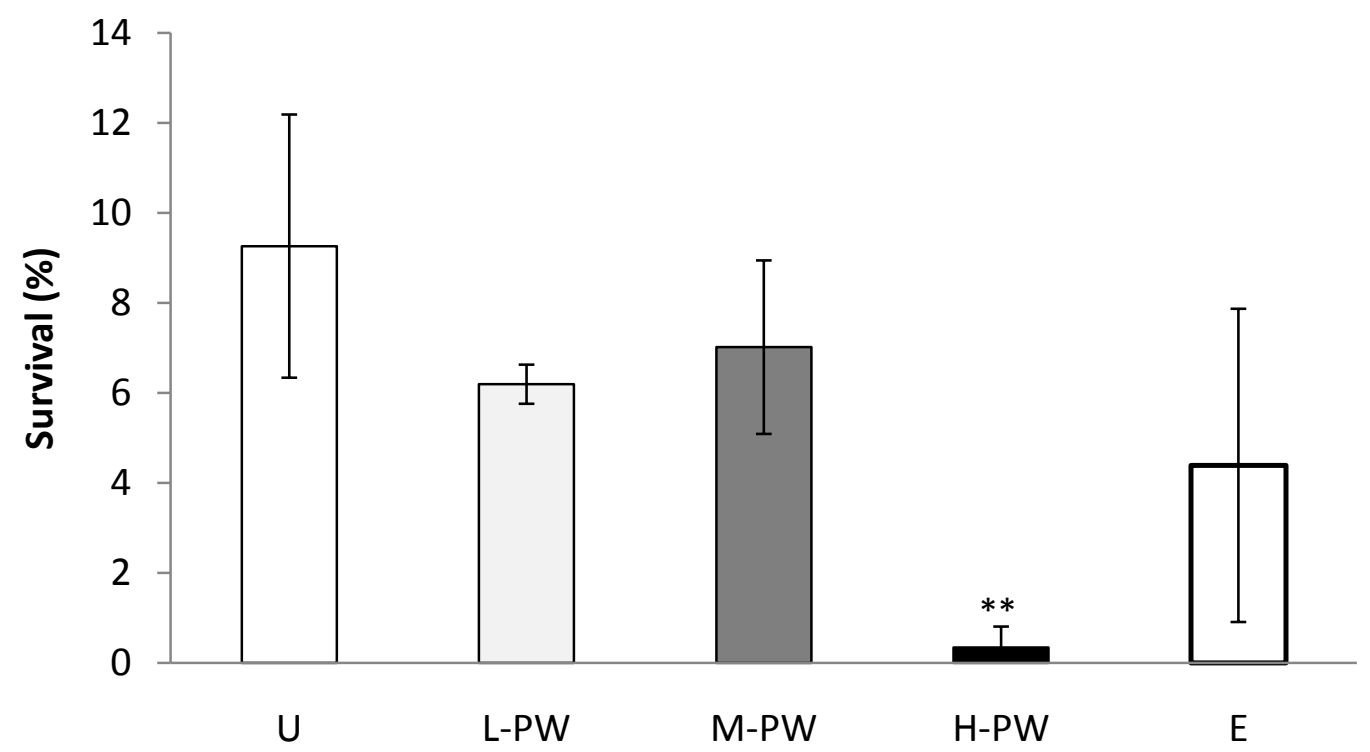




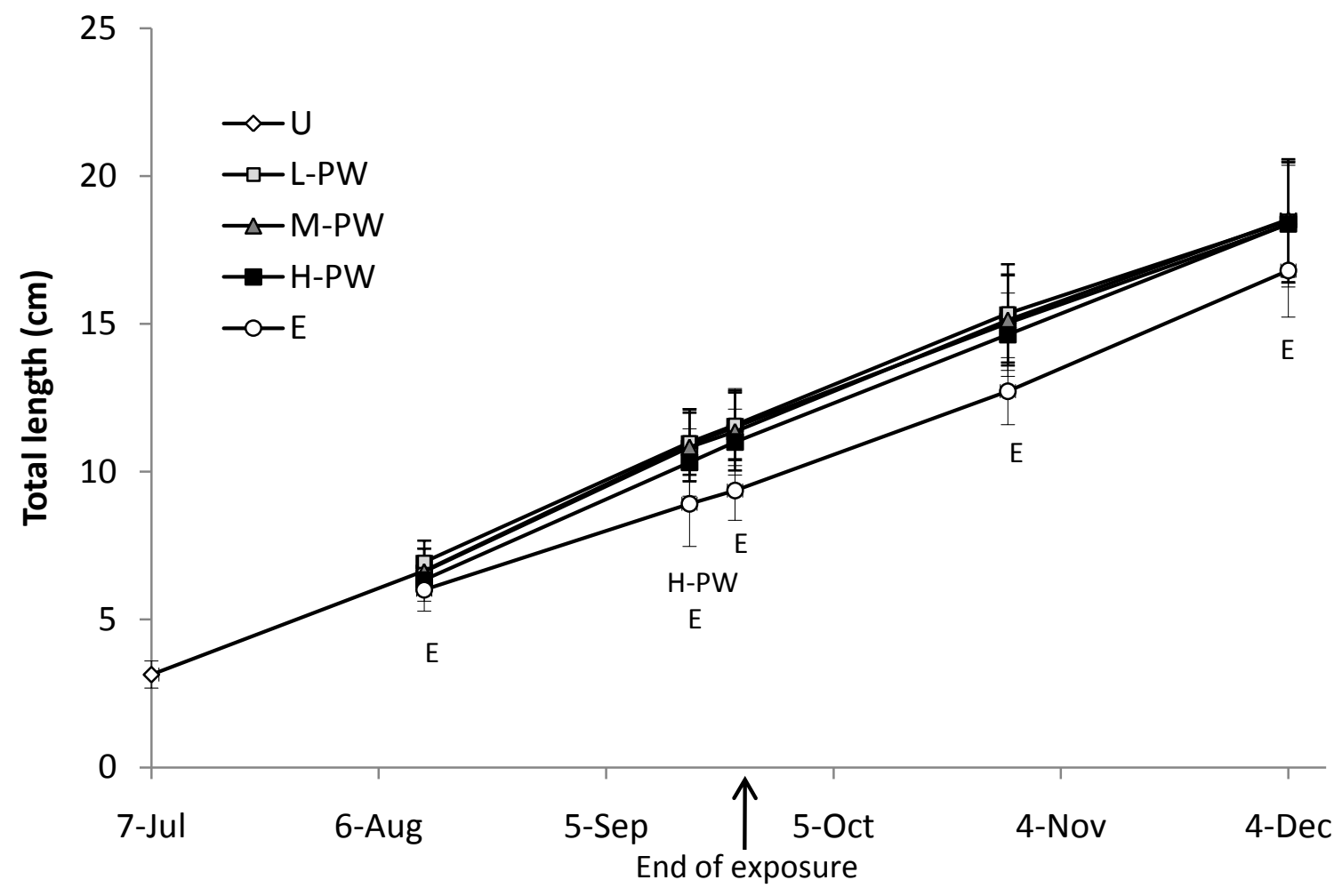




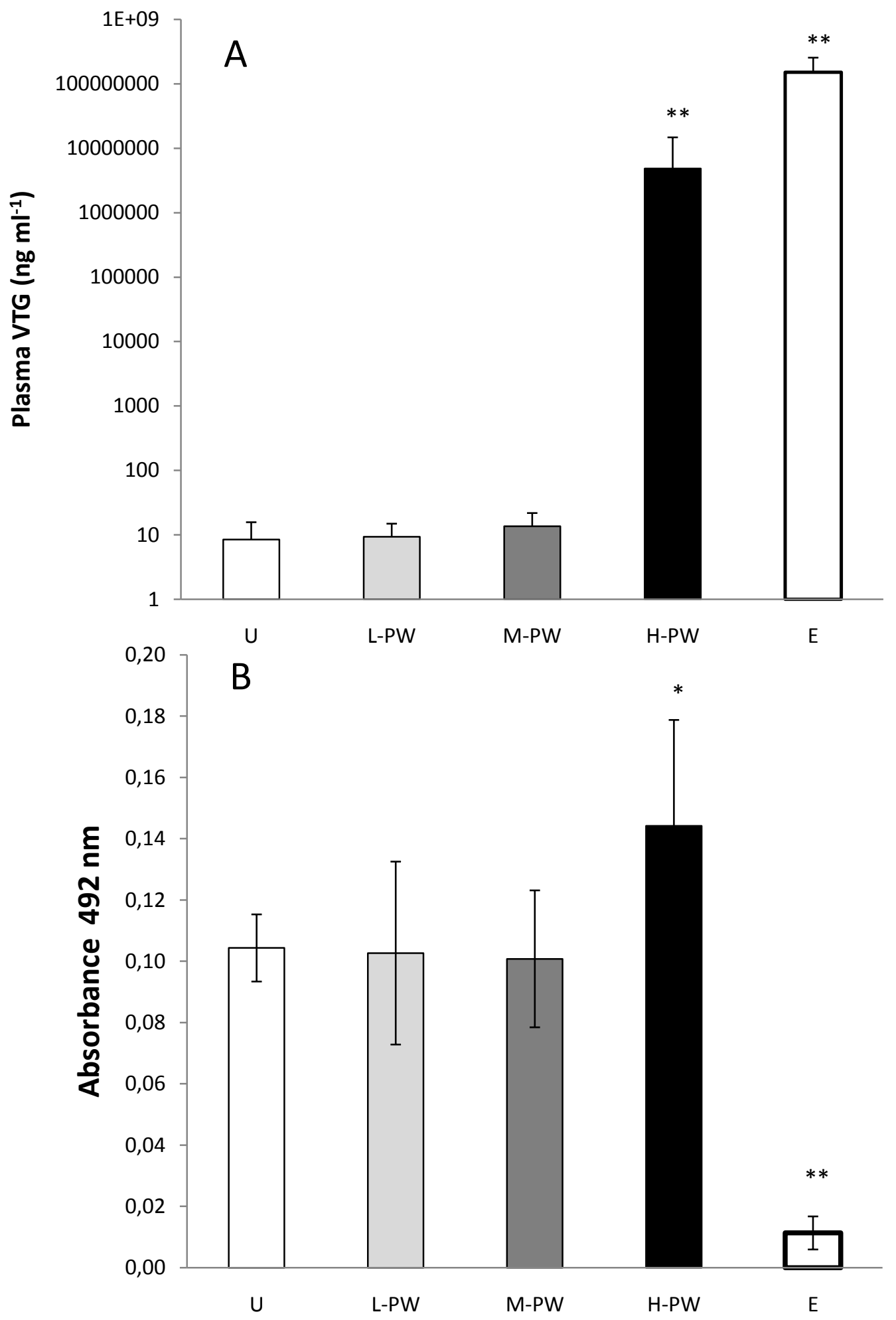

